Article

\title{
Digital Transformation in Banking: A Managerial Perspective on Barriers to Change
}

\author{
Florian Diener *(1) and Miroslav Špaček (1)
}

check for

updates

Citation: Diener, F.; Špaček, M. Digital Transformation in Banking: A Managerial Perspective on Barriers to Change. Sustainability 2021, 13, 2032. https://doi.org/10.3390/su13042032

Academic Editor: Andrea Pérez

Received: 28 December 2020

Accepted: 4 February 2021

Published: 13 February 2021

Publisher's Note: MDPI stays neutral with regard to jurisdictional claims in published maps and institutional affiliations.

Copyright: (c) 2021 by the authors. Licensee MDPI, Basel, Switzerland. This article is an open access article distributed under the terms and conditions of the Creative Commons Attribution (CC BY) license (https:/ / creativecommons.org/licenses/by/ $4.0 /)$.
Department of Entrepreneurship, Faculty of Business Administration, Prague University of Economics and Business, 13700 Prague, Czech Republic; miroslav.spacek@vse.cz

* Correspondence: florian.diener@vse.cz; Tel.: +49-(0)151-4053-2978

\begin{abstract}
The digitalisation of banks is seen as the omnipresent challenge which the banking industry is currently facing. In this digital change process, banks are facing disruptive innovation that requires adaptation of almost all cooperative processes. Digital transformation in the financial industry is associated with obstacles that seem to hinder smooth implementation of digital approaches. This issue has not been adequately addressed in the current academic literature. The main purpose of this qualitative exploratory study is to identify the main perceived obstacles to digital transformation in both the private and commercial banking sectors from a managerial point of view and to analyse them accordingly. The methodology is based on a methodological approach using a combination of contextual interviews with German board members of banks, inductive content analysis, and the exploration of best-practice approaches. The findings revealed that elements of strategy and management, technology and regulation, customers, and employees receive a high level of attention within the digital transformation. The other main barriers can be found in the areas of market knowledge and products, employee and customer participation, and public benefit. Each main barrier is characterised by several sub-barriers of varying importance for the digital transformation of banks and is described in detail.
\end{abstract}

Keywords: bank; barriers; digitalisation; management; perception; transformation

\section{Introduction}

Over the past several years, digital transformation has received considerable attention in the areas of management, business, information systems, information technology, and marketing. The developments in information and communication technologies in the digital age have significant and varying effects on organisations. Changes in traditional business ecosystems have created new business environments called "digital business ecosystems". Changes in the business ecosystems affect the strategic decisions of the organisations related to the internal and external environment. The size and frequency of these changes are the parameters that make the concept of change more meaningful [1]. The rapid development of technology, as well as a great variety of changes in today's global marketplace, have led to the intensification of a new cooperative adaptation process. This digital transformation and the adoption of new technologies raise a growing number of questions about the changes that traditional companies, strategies, and management practices need to implement in order to respond to them [2]. This response involves the creation of new, innovative business models and/or changes and improvements to the existing business models with the help of digital technologies [3]. The application of these new technologies and their appropriate implementations to improve business performance is an important issue for companies [4,5]. Today, complex transformations affect many dimensions, including strategic direction, competitiveness, business model, decision-making, innovation itself, entrepreneurship, productivity, and customers [6-8]. Based on further continuous development and ever-increasing digitalisation of lifestyles and changes in 
customer behaviour [9-12], the world has become more and more informed, transparent, and efficient. Thus, new sales and service markets are coming into being, with continuous changes in technology and customer behaviour [9-12]. As a result, traditional business models in multiple industries are not just competing with each other, but also with new models that are external to their business fields [13]. To satisfy these market-based changes, enterprises have to adjust by reconsidering and reforming their traditional base [14,15].

Industrial companies, various administrations, educational institutions, the financial sector, etc., are all undergoing digital changes, which have a noticeable impact on them. One of the main drivers of digital economy development is the financial sector, which takes the second position, just behind telecommunication [16]. The key underlying process is the digital transformation of financial service systems through financial technology (FinTech)_disruptive innovations by new market entrants that challenge the position of mainstream financial institutions [17]. In particular, retail banks have been at the forefront of technological revolution, characterised by rapid deployment and innovation of digital services, exponential pace of change, and innovative breakthroughs that alter conventional banking practice [18].

The main problem in banking seems to be that traditional financial service providers have not yet implemented comprehensive digitalisation [19-22]. As a result, they often offer an incomplete range of services and are confronted with both strategic and operational barriers within the digital transformation process. In contrast to established service providers, there are new, innovative competitors with new concepts, products, and services [23] - and, above all, with a modern multi-channel approach in terms of distribution, communication and marketing, which approaches customers in a variety of ways. As a result, multi-channel business models have gained substantial market shares, as, for example, in the case of the German company N26 [24]. Recent research confirms the growing and prospective influence of these business models on the finance industry [25]. As traditional companies and their industries adapt slowly and ineffectively to the modern changing markets, there is a high risk of disruption caused by new technologies and business models $[26,27]$. "If such changes are missed by system-relevant financial institutions, such as large banks or groups of smaller ones, then financial services and the whole economic system will be endangered" [28]. Many existing financial service providers have already recognised the need for basic changes in their business model, and have started to rethink, or rather reform, their approaches [29,30].

This aspect of market-driven technological change, in particular, raises the overall question of how new entrepreneurial approaches, management behaviour, and technology changes in the world of banking, a long-established financial system, as well as how they influence and change banking adjustment, thus leading to the following two research questions (RQ):

RQ1: What are the main barriers to smooth implementation of digitalisation in banking?

RQ2: What are the "best practices" that are applicable in the implementation of the digitalisation process?

Due to a complex adjustment process within the financial system and its all-encompassing entrepreneurial influence, the identification and analysis of obstacles that hinder digital adaptation in the context of an all-encompassing digitalisation is of great institutional importance. For this reason, this paper contributes to the issue of digital bank transformation and identifies obstacles to digital transformation in the sector from the perspective of the management, as the management is ultimately responsible for appropriate bank development and long-term business success. In line with this research objective, the present study identifies and analyses implementation barriers to digitalisation using a methodological approach based on a combination of contextual interviews with bank executives, inductive content analysis, and exploration of multiple best-practice approaches. 


\section{Literature Review}

Digital transformation is a holistic concept that includes technologies, as well as organisational and strategic changes [31]. Moreover, it is the process that an organisation goes through when it changes from an outdated approach to new ways of working and thinking by using digital, social, mobile, and new technologies [32]. It is driven by the advancement in technology, the appearance of new business models, and changes in expectations of the customer [33]. Several additional definitions of the term "digitalisation" are now commonly accepted. According to Gartner [34], digitalisation represents improvement of existing business models, creation of new revenues, and value-adding opportunities with the help of digital technologies. It can be understood as a complex issue that encompasses several areas like (i) shifts in thinking, (ii) changes in leadership, (iii) technology adoption, (iv) digitalisation of resources, and (v) acceptance of innovation [35]. As became apparent from the preceding classification, the term "digitalisation" should be distinguished from the similar term, "digitisation"; the former rather addresses the impact of digital technologies on the organization, while the latter represents the shift from an analogous solution to a digital one. Digitalisation is organizational renewal through new information and communication technologies [36]. According to Matt et al., digital transformation is a complex issue that proceeds within a framework that includes (i) changes in value creation, (ii) structural changes, and (iii) use of technologies and financial aspects [31]. It is no surprise that digital transformation seems to be blocked by a set of barriers that may hamper or even collapse the whole process of transformation. Digital transformation is considered a driving factor that offers a solution to the challenges currently faced by the banks. The core digital transformation practices, such as leadership, digital trends, digital transformation skills, digital strategies, implementation of digital technologies, and a customer-centric approach, are seen as influences brought to bear on digital maturity levels [37].

The term digital transformation (sometimes nicknamed digital entrepreneurship) is often misunderstood as a straightforward deployment of the latest information and communication technologies. In practice, technological investments entail not only risk, but also require an understanding of the relationship between technological and organisational culture and institutional change within certain boundaries of regulatory frameworks. Digital transformation is far from simple, certain, or predictable. Moreover, it is likely to be disruptive or transformative, with immutable impacts upon associated organisational outcomes related to technical capabilities and behaviours [18].

In the face of the established regulatory standards known as Basel III, banks aim to embark upon new technology standards, like Regulatory Technology (RegTech), which may facilitate digital transition. RegTech is an emerging technological trend that leverages information technology and digital innovations that can greatly assist with a bank's regulatory management process. It is advisable to incorporate RegTech into the digital transformation strategy of a management function, such as a treasury. Integrated adoption would mean that the digital platform can be deployed to support both strategic management activities and enhanced regulatory processes within the treasury. With this arrangement, commercial and prudential objectives are put in alignment [38].

Digitalisation plays a major role in contributing towards the United Nations Sustainable Development Goals. Without transformation of existing businesses, both economic and environmental challenges of the future cannot be solved sustainably [39]. Digital transformations will produce new social groups-partly human, semi-human, or nonhuman - some of which already exist, and some which can be foreseen by extrapolating from recent developments in the field of brain wearables, robotics, and software engineering. Growing dependency on digital services and tools may pose problems for both individuals and organisations [40]. Forcadell et al. [41] argue that digitalisation entails challenges that can hinder the potential benefits and compromise their survival. That is why corporate sustainability plays a significant role in enforcing digitalisation. It may compensate for drawbacks of digitalisation. In particular, the combination of corporate sustainability and digitalisation helps transform the organisational nature of banks by 
simultaneously narrowing their boundaries and expanding their scope. El Hilali et al. [42] drew attention to possible ways of reaching sustainability during digital transformation processes. They found that the companies achieved sustainability when effectively mastering customers, data processing, and innovation. On the other hand, they did not prove that the competition played a significant role in enhancing the companies' commitment to sustainability. This opinion was partly endorsed by Ordieres-Meré et al. [43], who confirmed the positive effects of knowledge creation facilitated by direct or indirect application of digitalisation. Technology is reported to disrupt the financial industry, solve friction points for consumers and businesses, and make the overall business more resilient and sustainable. Sustainable financial technology may contribute to the overall stability of the financial system as well [44]. Established technology-based business models can act as a sustainability catalyst to trigger collaborative innovations between traditional financial and banking institutions [45].

Effective risk management, including its diversification, is also ranked among the contributors to sustainable bank development in the global economy [46]. Examination of risk-mitigation strategies in Southeast Asia proved that the banks had become more sustainable when implementing viable risk-mitigation strategies [47].

Nevertheless, when it comes to the barriers to change in the implementation of digitalisation in the banking sector, few resources can be found in the literature. It is evident that the banking sector is changing and institutions have to adapt to new technological developments and customer behaviour. This trend is particularly evident in the increasingly digital user behaviour, as mentioned in Table 1, to which bank executives have to respond.

Table 1. Share of payment instruments in Germany.

\begin{tabular}{|c|c|c|c|c|c|c|c|c|c|}
\hline & \multicolumn{2}{|c|}{ Revenue 2008} & \multicolumn{2}{|c|}{ Revenue 2011} & \multicolumn{2}{|c|}{ Revenue 2014} & \multicolumn{2}{|c|}{ Revenue 2017} & \multirow{2}{*}{$\mathrm{CAGR}^{3}$} \\
\hline & $€$ & $\%$ & $€$ & $\%$ & $€$ & $\%$ & $€$ & $\%$ & \\
\hline cash & 405,486 & $57.89 \%$ & 317,137 & $53.10 \%$ & 267,249 & $53.18 \%$ & 297,901 & $47.58 \%$ & $-2.16 \%$ \\
\hline debit card & 178,829 & $25.53 \%$ & 169,093 & $28.31 \%$ & 147,592 & $29.37 \%$ & 212,576 & $33.95 \%$ & $3.22 \%$ \\
\hline credit card & 25,538 & $3.65 \%$ & 44,369 & $7.43 \%$ & 19,582 & $3.90 \%$ & 27,578 & $4.40 \%$ & $2.12 \%$ \\
\hline contactless payment & - & - & 318 & $0.05 \%$ & 386 & $0.08 \%$ & 7103 & $1.13 \%$ & $66.50 \%{ }^{1}$ \\
\hline other cards & 5127 & $0.73 \%$ & 815 & $0.14 \%$ & 486 & $0.10 \%$ & 676 & $0.11 \%$ & $-19.16 \%$ \\
\hline bank transfer & 62,199 & $8.88 \%$ & 49,181 & $8.23 \%$ & 26,405 & $5.25 \%$ & 34,749 & $5.55 \%$ & $-5.09 \%$ \\
\hline direct debit & 13,024 & $1.86 \%$ & 4268 & $0.71 \%$ & 14,881 & $2.96 \%$ & 15,181 & $2.42 \%$ & $2.99 \%$ \\
\hline online payment & 1939 & $0.28 \%$ & 10,115 & $1.69 \%$ & 13,986 & $2.78 \%$ & 23,258 & $3.71 \%$ & $33.45 \%$ \\
\hline mobile payment & - & - & - & - & 77 & $0.02 \%$ & 124 & $0.02 \%$ & $8.63 \%{ }^{2}$ \\
\hline other techniques & 8297 & $1.18 \%$ & 1984 & $0.33 \%$ & 11,900 & $2.37 \%$ & 6955 & $1.11 \%$ & $-0.71 \%$ \\
\hline$\sum$ & 700,439 & $100 \%$ & 597,280 & $100 \%$ & 502,544 & $100 \%$ & 626,102 & $100 \%$ & \\
\hline
\end{tabular}

Note: ${ }^{1}$ CAGR (Compound Annual Growth Rate) calculated for 2011-2017. ${ }^{2}$ CAGR calculated for 2014-2017. ${ }^{3}$ Possibility of bias due to different sample sizes $(n)$ and individual transaction levels. Source: Authors' own representation based on Deutsche Bundesbank [9-12].

Financial technology (companies called FinTech(s)) plays an essential role here. It is an industry composed of diversified firms that combine financial services with innovation technologies offered to financial service providers [44]. Shin and Choi [48] define FinTechs as platforms for the development of sustainable economic growth as well as a prompter of the fourth industrial revolution. These types of companies have several advantages over traditional banks. Typically, FinTechs may also provide a solution for sustainable finance through microfinance or crowdfunding, among others. Moreover, some FinTechs distribute insurance and other financial instruments or provide third-party services. FinTechs promise to disrupt and reshape the financial industry by cutting costs, improving the quality of financial services, and creating a more diverse and stabler financial landscape. Their existence is driven by sharing and the circular economy, as well as favourable regulation, and information technology [44]. FinTechs have the potential to unbundle core activities of the banking sector: clearing and settling payments, performing maturity transformations, sharing risks, validating trust, and allocating capital. They have also 
created a new paradigm in which information technology represents a meaningful driving force that gives rise to innovation [44].

Hereby, banks are under massive pressure to transform their approaches and business models to a more customer-centric approach in order to remain competitive. The traditional institution has felt the disruption and is working towards changing its business model from product-centric to customer-centric [37]. Similarly Mărăcine et al. [49] suggest that five main areas exist where FinTechs can provide improvements in business models for the banks: introducing specialized platforms, covering neglected customer segments, improving customer selection, reduction of the operating costs of the banks, and optimisation of the business processes of the banks. As digital banking offerings have matured and cost pressures have increased, it has become inevitable to make changes to the operating models of banks. Driven by the sub-optimum performance of the existing business model, the "digital" concept has evolved into more than a channel for accessing services. One of the outcomes was a full-fledged branchless digital bank [50] or challenger bank. A challenger bank stands for a financial institution that can be presented in the plain form of an information-communication system [16].

Sadigov et al. [51] have proved that FinTech development contributes to economic growth by increasing the GDP generated in the financial sector, and indirectly does so by increasing e-commerce turnover and real sector financing, particularly by creating more favourable lending conditions for small and medium-sized businesses.

As has become evident, business models adopted by FinTechs differ from those applied by traditional banks. Nevertheless, these differences do not mean that both types of banks may eventually converge towards a common market by exploiting co-operation strategies. Their business model is intangibly driven, combining e-finance, internet technologies, social networking, artificial intelligence, blockchains, and big data analytics. Moreover, their revenue model is much more scalable than that of a typical bank [44].

Given the lack of literature on banking and existing research that followed a similar approach to identifying implementation barriers, those by Chan [52], Chan [53], Vikneswaran and Anantharajah [54], Kamalulariffin et al. [55], and Yusof and Jamaludin [56] have to be considered; barriers arise in connection with the implementation of new strategies and management approaches. Given that these authors have already properly elaborated and investigated the barriers to the implementation of new strategies, it is important to take their research approaches into account.

In addition, the questionnaires they used have already been partially validated and can, therefore, be a sound basis for this study. For some barriers, however, their questionnaires need to be reformulated or reworded, as they only allow a theoretical approach and do not fully correspond to the specific terminology needed for this work. For example, the study by Kamalulariffin et al. [55] focussed on environmental management in the hotel sector; a closer look at the research findings revealed that this industry is facing a situation similar to that which financial institutes are facing today, with new strategies and business models being pursued internally and by competitors. In particular, new business models are being developed that have never been established in their market before, thus satisfying customer needs in the latest way and, at the same time, endangering traditional business models.

Chan $[52,53]$ already considered internal and external barriers, which he repeatedly validated through his work. These findings can be summarised as (a) implementation and maintenance costs, (b) lack of knowledge and skills, (c) lack of a sense of urgency, (d) the ambiguity of modern banking, (e) lack of qualified consultants, (f) lack of motivation and professional advice, (g) conflicting guidance, (h) outcome uncertainty, and (i) inconsistent support.

Kamalulariffin et al. [55] mentioned the barriers of (a) regulation and government, (b) customer demand, (c) level of competition, (d) cost of greenness at the organisational level, and (e) attitude toward change. Vikneswaran and Anantharajah [54] referred to (a) high maintenance and implementation costs, (b) lack of sufficient knowledge, (c) lack 
of resources (time, manpower, equipment, and money), (d) lack of momentum from the company owners, (e) lack of a sense of urgency and ambiguity of guidelines, (f) lack of qualified verifiers or consultants, (g) conflicting guidance, and (h) lack of government regulations and enforcement, as well as (i) difficulty in operating an entity (difficult to balance the quality of service performance). From the content analysis of all the related literature, in summary, 12 pertinent barriers were identified by Yusof and Jamaludin [56]. Chan et al. $[57,58]$ confirmed and extended these results again, which can also be interpreted in relation to banking, the associated digitalisation, and FinTech. Due to the more appropriate and transparent approach of Yusof and Jamaludin [56], their analysis is not considered holistically in this elaboration.

Due to the holistic nature of these works, these results served as a textual foundation for the preparation of the interview questions; consequently, they were derived mainly from the proven works of Chan [52], Chan [53], Vikneswaran and Anantharajah [54], Kamalulariffin et al. [55], and Yusof and Jamaludin [56], which are considered reliable and valid.

\section{Methodology}

\subsection{Data}

Due to their strong market positioning, the German savings banks and cooperative banks were the focus of this study and, thus, the focus of the data collection process. Both types of banks are equally ranked among the good service providers. They provide the majority of regional and supra-regional branches in retail banking and are the most strongly represented group in banking from a personnel point of view [59-63]. In addition, they offer an almost identical product range to their customers. Although they differ only marginally in their products and services, they differ on an organisational and structural level with regard to their business model [64].

\subsubsection{Interview Process}

In total, for this study, 34 interviews were conducted with German bank managersmore precisely, bank executives. Two of them had to be disregarded, as they did not fit into the relevant target group; thus, 32 interviews, with an average interview duration of $34 \mathrm{~min}$, were considered for further evaluation. The valid interviews lasted between $22 \mathrm{~min}$ in the shortest case and $1 \mathrm{~h}$ and $7 \mathrm{~min}$ in the longest case; the total length of the interviews was $17 \mathrm{~h}$ and $53 \mathrm{~min}$. Two of the 32 valid interviews were interrupted, either due to technical problems or due to interruptions in the person's environment, so in these cases, several recording files were created for each interview; however, this does not affect the validity and substance of the discussions.

These were determined as Table 2. 
Table 2. Numerical interview data description.

\begin{tabular}{|c|c|c|c|c|c|}
\hline \multirow{2}{*}{ Interview } & \multirow{2}{*}{$\begin{array}{c}\text { Duration } \\
\text { (mm:ss) }\end{array}$} & \multirow{2}{*}{$\begin{array}{c}\text { Bank Experience } \\
\text { (In Years) }\end{array}$} & \multirow{2}{*}{ Gender } & \multirow{2}{*}{ Validity } & \\
\hline & & & & & \\
\hline 1. & $27: 57$ & 20 & $\mathrm{M}$ & $\checkmark$ & \\
\hline 2. & $31: 25$ & 5 & $\mathrm{M}$ & $\checkmark$ & \\
\hline 3. & $24: 15$ & 42 & M & $\checkmark$ & \\
\hline 4. & $38: 57$ & 9 & M & $\checkmark$ & \\
\hline 5. & $23: 02$ & 17 & $\mathrm{M}$ & $\checkmark$ & \\
\hline 6. & $23: 48$ & 33 & $\mathrm{M}$ & $\checkmark$ & \\
\hline 7. & $13: 12$ & 25 & $\mathrm{M}$ & $x$ & \\
\hline 8. & $39: 39$ & 32 & M & $\checkmark$ & \\
\hline 9. & 29:04 & 7 & $\mathrm{M}$ & $\checkmark$ & \\
\hline 10. & $25: 24$ & 20 & M & $\checkmark$ & \\
\hline 11. & $28: 05$ & 17 & $\mathrm{M}$ & $\checkmark$ & \\
\hline 12. & $34: 19$ & 8 & M & $\checkmark$ & \\
\hline 13. & $27: 03$ & 27 & M & $\checkmark$ & \\
\hline 14. & $34: 46$ & 34 & $\mathrm{M}$ & $\checkmark$ & \\
\hline 15. & $27: 13$ & 11 & M & $\checkmark$ & \\
\hline 16. & $66: 58$ & 22 & $\mathrm{M}$ & $\checkmark$ & \\
\hline 17. & $46: 48$ & 19 & M & $\checkmark$ & \\
\hline 18. & $25: 57$ & 28 & $\mathrm{M}$ & $\checkmark$ & \\
\hline 19. & $34: 48$ & 12 & M & $\checkmark$ & \\
\hline 20. & $31: 49$ & 26 & $\mathrm{M}$ & $\checkmark$ & \\
\hline 21. & $35: 18$ & 30 & M & $\checkmark$ & \\
\hline 22. & $38: 02$ & 17 & $\mathrm{M}$ & $\checkmark$ & \\
\hline 23. & $35: 59$ & 28 & $\mathrm{M}$ & $\checkmark$ & \\
\hline 24. & $22: 54$ & 23 & M & $\checkmark$ & \\
\hline 25. & $52: 55$ & 20 & M & $\checkmark$ & \\
\hline 26. & $46: 59$ & 10 & M & $\checkmark$ & \\
\hline $27 . / 28$ * & $54: 05$ & $44 / 11$ & $\mathrm{M}$ & $\checkmark$ & \\
\hline 29. & $37: 31$ & 25 & M & $x$ & \\
\hline 30. & $28: 43$ & 30 & $\mathrm{M}$ & $\checkmark$ & \\
\hline 31. & $33: 31$ & 20 & M & $\checkmark$ & \\
\hline 32. & $35: 14$ & 27 & M & $\checkmark$ & Duration (hh:mm:ss) \\
\hline 33. & $37: 02$ & 20 & M & $\checkmark$ & $\sum$ (total) 18:43:56 \\
\hline 34. & $31: 14$ & 25 & M & $\checkmark$ & $\sum$ (valid) $17: 53: 13$ \\
\hline
\end{tabular}

Source: Authors' own representation.

\subsubsection{Data Preparation}

The data were prepared by transcription according to "simple rules", whereby the audio recordings were transcribed word by word, but not repetitions, word deletions, or non-verbal utterances. Signals of understanding or confirmation, such as "mhm, aha, yes, exactly", etc., were not transcribed. The form of the transcription was based on Kuckartz [65] and Dresing and Pehl [66]. The interviews were transcribed verbatim, but dialectal variants were not transcribed, and slight dialectal utterances were translated in the standard language. Colloquial language was retained. The sentence form, definite and indefinite articles, etc. were retained, even if they contained errors.

\subsection{Analysis Procedure}

By means of an explorative interview framework [67], the main goal of this study was to generate impulses for an individual narrative of implementation barriers in digital transformation. In guided interviews, pre-defined questions were asked, but these could be answered very openly by interviewees; the procedure was less strict than in other interview methods. In a semi-structured interview, also called a guided interview, the interviewees are not given specific answers; they can report, comment, and explain freely. The advantage of this method is that, although the interviewer asks concrete questions by means of his or 
her questionnaire, the interviewee can answer openly and possibly focus the interview on new aspects and expand the entire interview.

Following Mayring [68], a theory-based analysis model was set up for the analysis, which was carried out by summarising and through inductive category formation. The selection of interviewees, as well as the number and scope of the answers given, is of crucial importance in the interview method [69]. As is the case in similar work on expert knowledge, the quality depends crucially on the selection of so-called experts-in this case, the interview participants [69]. Experts are understood to be individuals to whom knowledge of the surveyed topic area is attributed due to their activity and resulting practical expertise, as well as their specific educational qualifications [70]. This usually exceeds the knowledge of people who are unfamiliar with the topic being surveyed [71]. According to Chan [52], these are the managers and executives of an industry. For this study, interviewees are bank experts who are the actual decision-makers (the executive management) of a bank, with budget and personnel responsibility, as well as bank experts with specific knowledge and professional experience in the fields of banking, digitalisation, entrepreneurship, finance, financial technology and innovation, and many more.

A larger sample often leads to more confident and more reliable statements on what to look for [69]. The size of the samples for qualitative analyses is usually smaller than for quantitative analyses. Frequently, more accurate and more representative inferences about the population can be made in the case of large sample proportions; however, interviews will only be carried out as long as new information is perceived. In principle, the sample sizes should be large enough to obtain sufficient data to adequately describe a phenomenon of interest and to enable the research questions to be answered. The aim of this and all other qualitative studies is to obtain saturation of the sample; saturation occurs when the inclusion of additional participants does not lead to new perspectives or information. Glaser and Strauss [72] suggested the concept of saturation in order to achieve an appropriate sample size in qualitative studies. A number of guidelines have been developed for this purpose. Morse [73] suggested about 30-50 interviewees in ethnography for grounded theory. Creswell [74], in contrast, suggested only 20-30, and possibly as few as 5-25 for phenomenological studies, and Morse [73] suggested at least six.

The population is understood to mean the total regional savings and cooperative, and private banks. It can be assumed that at least one decision-maker/expert can be assigned to a bank. However, it may also be assumed that the actual population is much greater, as banks are not authoritarian institutions and their decisions are not made by one person alone; the prevailing ownership and organisation structures have an additional impact on a bank's business orientation.

In the context of explorative inductive content analysis with category formation, one can rely on work that has already been done. According to Mayring [75], the basic principle of inductive content analysis is that categories are derived directly from the respective research material in a generalisation process, without referring to previously formed theoretical concepts. When the terms "categories" and "barriers" are used in the following, they are synonymous and refer to the hurdles of digitalisation. Within the qualitative approaches, the inductive approach has great importance [76]. Its objective is to capture a naturalistic, object-like representation of the investigation material without distortion through presuppositions. This approach is a central process within "Grounded Theory" and is called "open coding" [75]. Within the analysis, this category-building process can be described as systematic, using a step-by-step and line-by-line approach. In this logic, the topic of category formation must first be determined on the basis of theory; i.e., a selection criterion is introduced that determines which material is intended to be the basis for further category definition. Insignificant contents are thus excluded from the analysis. The thematic question of the study is of great importance and in accordance with the main question of this study; it defines the focus of the content. Likewise, within this approach, the category dimensions and the level of detail have to be defined in advance, as well as the analysis units [68]. 
These were determined as Table 3.

Table 3. Category dimensions.

\begin{tabular}{cc}
\hline Evaluation question & $\begin{array}{r}\text { What obstacles do banks face when implementing digital banking } \\
\text { approaches according to the respondents? }\end{array}$ \\
Category definition & $\begin{array}{r}\text { Subjective as well as objective assessments and perceptions of } \\
\text { decision-makers and experts on the topic of digitalisation and the } \\
\text { associated implementation barriers. All related issues affecting the } \\
\text { industry and the specific situations of individual institutions in the } \\
\text { banking sector. }\end{array}$ \\
\hline Abstraction level & $\begin{array}{r}\text { Concrete content on the subject of digitalisation for people, } \\
\text { departments, companies, customers, and the market. }\end{array}$ \\
\hline Coding unit & $\begin{array}{r}\text { Clear and meaningful elements in the context of digitalisation in } \\
\text { banking and general financial services. }\end{array}$ \\
\hline Context unit & The whole interview with a person-verbatim transcription. \\
\hline Analysis unit & All valid research material from the 32 interviews. \\
\hline
\end{tabular}
Source: Authors' own representation based on Mayring [68].

The analysis approach to inductive content analysis with category formation follows a predefined process model, which is outlined in Figure 1.

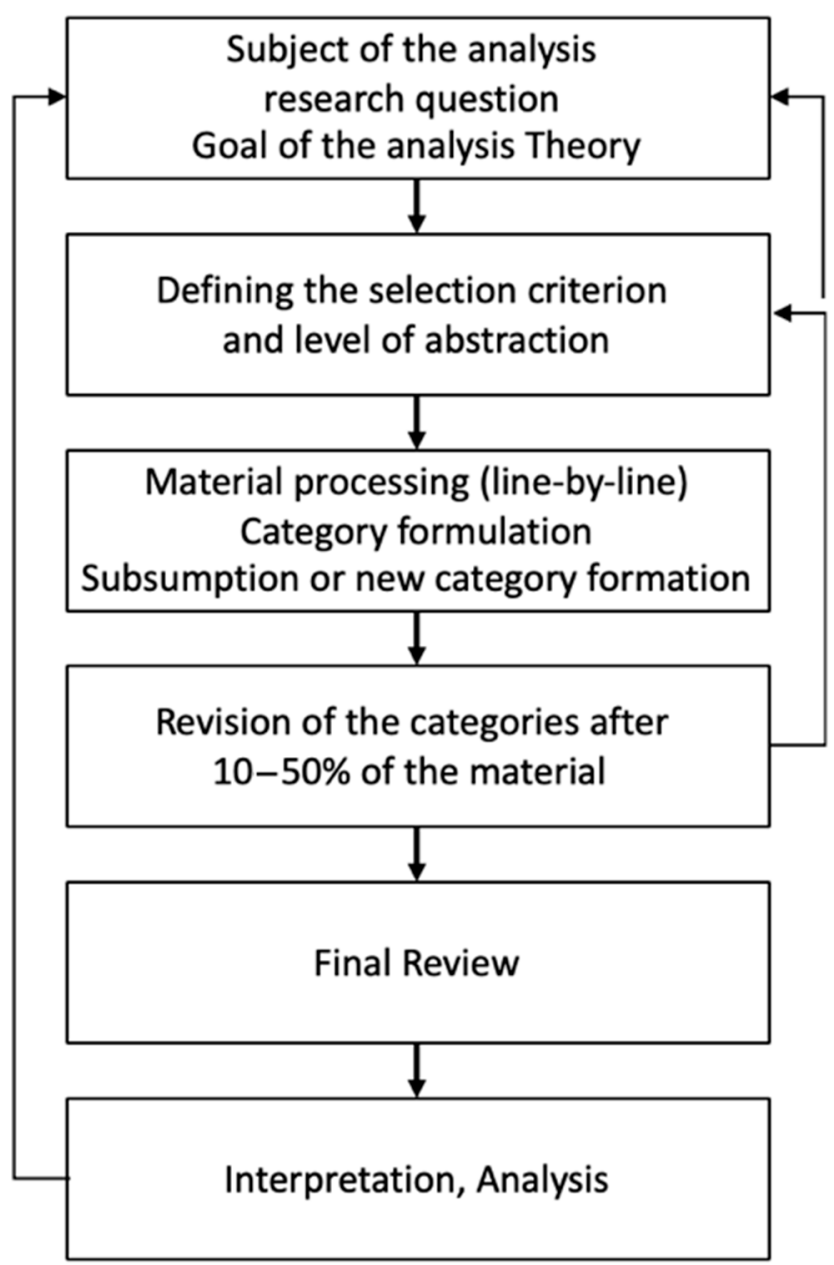

Figure 1. Sequences of inductive content analysis with category formation to illustrate the method of qualitative analysis according to Mayring [68,75]. 
In the analysis, taking into account the level of abstraction and the category definition, a suitable text passage is identified in the test material during the analysis, and a category is constructed. A term or phrase that comes as close as possible to the material is then used as the category name. Whenever a new passage is found in the further course of the text analysis that matches the selection criterion and category, it is also assigned to the same category. This is also referred to as "subsumption". However, if it turns out that no assignment to already existing categories is possible, a new category is inductively formulated from the specific material [75].

After a certain percentage of the material (often at 10 percent to 50 percent), when almost no new categories can be created, this is the moment for revision of the category system [68]. It is then necessary to check whether or not the logic is clear and the degree of abstraction fits the object and the question posed.

In the course of this qualitative analysis, the coded text passages are first paraphrased, then generalized, and finally form the actual category. The result of this process is a series of categories assigned to a specific topic and corresponding text passages in the research material. In the further course of the process, the interpretation is then made with regard to the overarching research question, taking into account the present approach and its findings. Due to the complexity of the interview topic, the respondents preferred to conduct the interviews in their first language. Given the availability of information, the generalised statements of the interviews were first formulated in German and later translated into English for this work. Thus, the internationality of the results is taken into account. In order to ensure the overall consistency of the generalisation, as well as the equivalence of the translations, a re-translation procedure was applied [77], carried out by a professional bilingual translator.

\subsection{Structure of the Interview Guideline}

The semi-structured interview guide was divided into a German and an English approach, depending on the interviewee. Both were based on previously extracted theoretical findings, which were used accordingly to interview decision-makers at banks. The barriers mentioned in Section 2 were fully taken into account. Furthermore, due to the different perspectives of the individual respondents, the guidelines were also adapted to each individual situation. They therefore differed slightly and were divided into two categories: banks and financial service providers. However, the basic structure of the interview guide was not changed. First, the interview topic was introduced and introductory questions about the person were asked. In the first section of the interview, the interviewees placed themselves in their respective positions in the company and described their level of knowledge on the topic of digitalisation in banking. This was to determine the suitability of each interview partner in advance. In the further course of the interview, questions regarding the banking sector and digitalisation were asked in detail, taking into account the findings of Chan [52], Chan [53], Vikneswaran and Anantharajah [54], Kamalulariffin et al. [55], and Yusof and Jamaludin [56].

\subsection{Conducting the Survey}

The guideline survey focused on interviews with decision-makers at banks. These were identified through personal contacts in the financial and banking industry and active approaches toward banking associations and local banks, as this is where access problems appear to be the lowest [70]. Furthermore, recommendations played an important role in the acquisition of interview partners. Consequently, further contacts with experts were established. Due to the geographical distance from the respective interview partners, the interviews were not exclusively conducted in person, but also via telephone or video conferencing [70].

In order to ensure the clarity of the individual questions, a pre-test with three test subjects was carried out in advance. As a result, the interview framework was confirmed, and no further adjustments had to be made. In order to comply with the applicable 
provisions of the General Data Protection Regulation (GDPR), respondents were required to sign a consent form. The interviews conducted were recorded using the memo function of a smartphone. Here, it is important to mention that all respondents were interviewed regardless of ethnic and social origin, age, gender, sexual identity, religion, ideology, or other ethically questionable aspects [78]. Furthermore, all of these interviews were voluntary and the participants consented to the GDPR.

\section{Qualitative Evaluation}

\subsection{Consistency of Coding}

In quantitative content analysis, the term "inter-rater reliability" is generally understood to refer explicitly to the quantitative quality criterion of reliability. The term is connected to measurement theory and claims to be replicable. Here, a distinction has to be made between a possible agreement in the formation or direct application of an existing category system. Since the formation of inductive categories according to Mayring $[68,75,76]$ is the result of a construction process, the formation of a category system cannot be claimed to be consistent [65]. A coefficient that measures the agreement between two category systems created by two or more different coders using the same data material says little about the quality of the category system. Rather, it could measure something that was not intended to be measured [65] — for example, the logic by which people create category systems. Accordingly, Kuckartz [65] concludes that the demand for agreement among coders thus refers primarily to the application of categories, i.e., the coding of data. However, the classical quality criteria for determining reliability in quantitative content analysis cannot be transferred to qualitative content analysis. Kuckartz [65] justifies this with the fact that, in quantitative content analysis, the coding units are defined before coding. In this quantitative case, relative matches and coefficients, such as Cohen's Kappa, Krippendorff's Alpha, or Scott's Pi would then be calculated [65]. In qualitative content analysis, the material is usually not segmented in advance, which is why Kuckartz sees two ways of identifying the concordance between coders, according to which the present study is oriented:

1. A qualitative path by means of the joint checking of codings, called consensual coding, and

2. a quantitative path by calculating percentage agreement and, under certain circumstances, a suitable coefficient [65].

\subsection{Consensus Coding}

Subjective assessment is understood by Kuckartz [65], referring to Guest, MacQueen, and Namey [79], as a situation in which two coders encode a text independently and then compare it subsequently. This process is also called consensual coding $[65,80]$. Here, the second coder notes questions and problems that arise in the process and discusses them at the end of the individual coding session. Using the formulated category definitions of disputed codes, a coding is agreed in the best case and, if necessary, the category definition is revised. If no consensus can be reached, another person is consulted, who then decides on the controversial case [65].

Since the qualitative data collection resulted in a total of 32 valid interviews, the second coder was provided with a selection of interviews. Due to the large amount of interview material, a complete second coding seemed unreasonable for an external coder. It was agreed that at least 10 to 30 percent of the interviews should be independently coded a second time, as this seemed to be feasible in terms of the time and motivation required. In order to ensure an independent selection of interviews, the principle of drawing random numbers ( 1 to 34) was applied with the help of a random number generator from Random.org. Interviews 7 and 29 were omitted; the respondents did not fit the target group because their business model was different from that of banks. Thus, a total of six interviews $(4,13,20,24,27 / 28,31)$ were coded by the second coder, which means that about 19 percent of the entire data material was used to verify the 
results. Furthermore, based on the sum of valid interviews, one is at least within the methodological revision range of 10 to 50 percent of the categories, which is consistent with Mayring's approach $[68,75,76]$.

Within the coding process, the second coder was first introduced to the developed coding system and the category set, including all sub-categories. For better interview analysis, MAXQDA Analytics Pro 2020 (Release 20.0.8), a qualitative analysis software, was used for the actual coding process.

In a personal meeting, classifications were discussed and definitional assignments were reconsidered. During this process, all six interviews were discussed step by step, or coding by coding. It is worth mentioning that the already provided coding set did not require any improvements and could be used by the second coder without additional modifications, or interpretation difficulties. In addition, there were no problems with the coding. Based on the fact that the second coder experienced the coding system as quite complex during familiarisation with the topic and approach, the first two coded interviews were revised a second time at the end of the coding process to increase reliability. At this stage of the qualitative evaluation, no numerical analysis of coders' agreement was carried out, since the interviews as a whole, rather than individual sections, were the subject of discussion and appropriate review.

\subsection{Calculation of Inter-Rater Reliability}

Inter-rater reliability (IRR) is a measure of the level of agreement between the independent coding choices of two (or more) coders [81-83]. Of course, it is expected that the allocation is not arbitrary, but that it is done in such a way that a certain reliability is achieved. In qualitative research, it is important to improve the agreement and to discuss together where there are differences in coding and why these differences exist. The MAXQDA Intercoder Matching function enables comparison of the codings of two persons coding independently of each other. It supports determination of the consistency of coding and can be used to establish the deviation of a coder's choices from the ideal or "true codes" ("true codes" are those that garner general consensus among multiple coders). There are a variety of statistics that can communicate a measure of inter-rater reliability, but one of the most common (and most appropriate for the study in question) is Cohen's kappa coefficient [84]. Cohen's kappa is considered one of the most robust measures of IRR and is used widely in science [85]. It is calculated based on the percentage of consistency between two or more coding collections and accounts for the possibility of chance consistency.

For further investigation, it is recommendable to define in advance the segments or citations to be coded. In the present analysis, due to the large amount of data, the selection refers to entire interviews and not to individual segments in order to ensure a holistic approach. Interviews were selected randomly, i.e., six interviews (4, 13, 20, 24, 27/28, 31). Only if this is the case does it make sense to calculate a coefficient to determine the concordance [65]. Based on the selected interviews, the evaluation checked whether the two coders matched in the coding of the individual segments and whether conclusions could be made regarding the reliability of the overall coding. The IRR approach is the comprehensive and typical variant of qualitative coding [84]. Since texts in qualitative evaluation procedures are often not divided into fixed text units, the verification of conformity is carried out by default for each segment encoded by the two coders (evaluation: segments of both documents). A percentage value was defined when two coded segments were considered to be a match. The default value was 90 percent. For this study, the value was set at 60 percent due to the high level of detail of the code set and the number of possible codings, as this allowed for more precise evaluations during the later discussion of the results with Coder 2. With this approach, at the end of the evaluation, for every 60 percent overlapping coded segment, there is a match that can be used for further analysis.

To interpret the Kappa values, ranges from 0.61 to 0.8 are considered acceptable agreement, and from 0.8 upwards, almost perfect agreement [65,86-88]. Further analysis of the relative number of matching codes was also carried out (see Table 4). The "Percent- 
age" column shows the percentage of matches per interview. This resulted in an overall percentage agreement of 84.66 percent. It was calculated as follows: Matches/(matches + non matches). In the "Kappa (RK)" column, the result table gives a randomly corrected value for the percentage match [83]. This takes into account the probability of two people randomly selecting the same codes in a document (if they would simply select codes randomly without considering the data material). The calculation only makes sense if the option "Unassigned codes as matches" is selected, which is the case here [83].

Table 4. Code consistency between documents.

\begin{tabular}{ccccc}
\hline File & Match & Non-Match & Percentage & Kappa (RK) \\
\hline Interview 4 & 57 & 6 & 90.48 & 0.90 \\
Interview 13 & 56 & 7 & 88.89 & 0.89 \\
Interview 20 & 53 & 10 & 84.13 & 0.84 \\
Interview 24 & 54 & 9 & 85.71 & 0.86 \\
Interviews 27 and 28 & 46 & 17 & 73.02 & 0.73 \\
Interview 31 & 54 & 9 & 85.71 & 0.86 \\
<Total> & 320 & 58 & 84.66 & \\
\hline
\end{tabular}

Source: Authors' own representation based on MAXQDA.

In determining the kappa coefficient, "P observed" represents the simple percentage of agreement. The calculation of "P chance", the random match, is based on the calculation by Brennan and Prediger [89], who have intensively studied the optimal application of Cohen's kappa and its problems with unequal marginal sum distributions. Using this calculation method, the random match is determined by the number of different categories used by both coders. This corresponds to the number of codes in the "code specific result table". The calculation of Cohen's kappa of the randomly selected interviews resulted in a value of 0.68 after a renewed review of the coded sequences with Coder 2, which can be regarded as a substantial agreement and supports the code set (Figure 2).

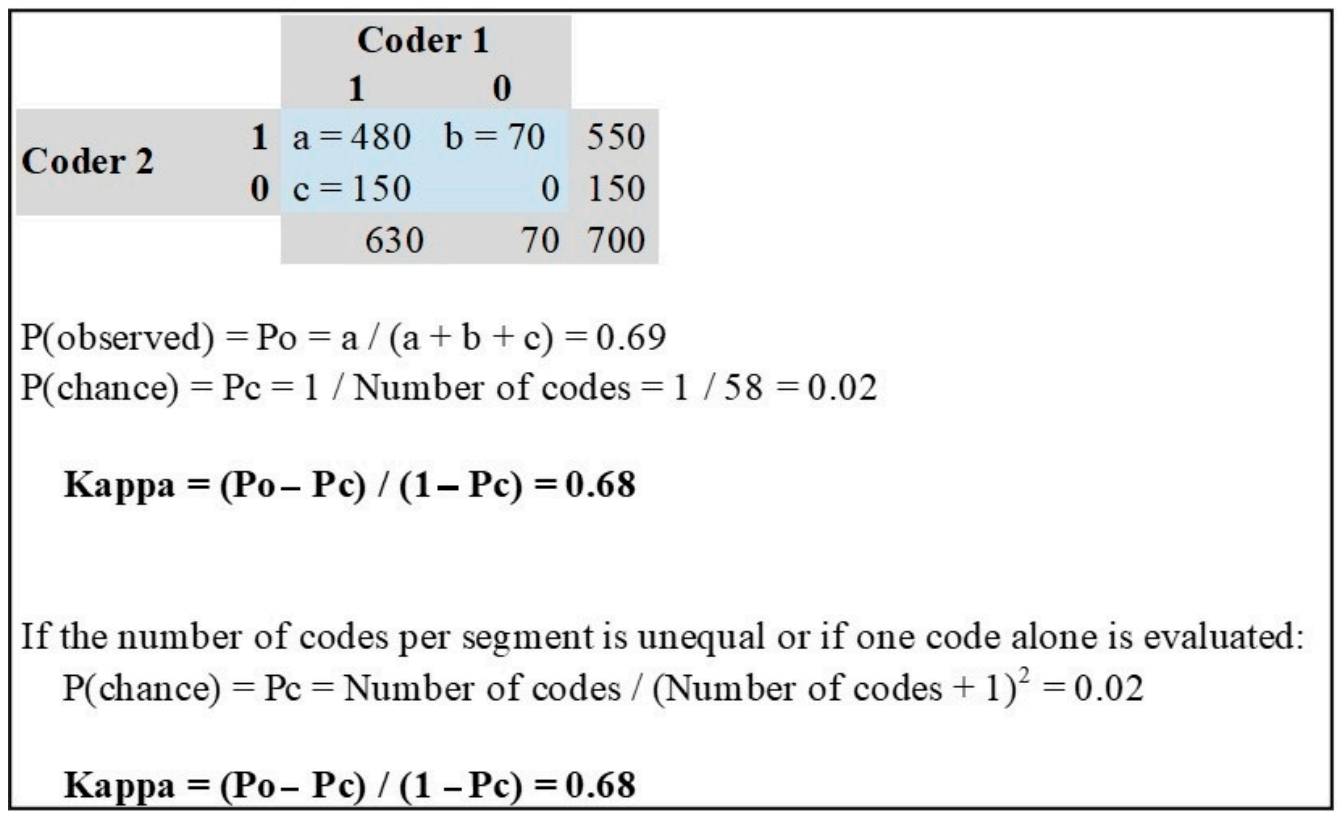

Figure 2. Calculation of the overall kappa coefficient values based on MAXQDA, representing results by Coder 1 and 2 .

When classifying the resulting characteristics of the IRR, it should be taken into account that the second coding was carried out under honorary conditions of a scientific research assistant to a professor and not under the conditions of a paid scientific research group. 
Against this background and the fact that six interviews were double-coded holistically and not just isolated sections, the reported results appear significant for further interpretation.

\section{Results}

The analytical approach enabled us to answer the two research questions formulated above, which are answered in more detail in this chapter. The first RQ referred to the contribution to theory, while the second referred to the contribution to practice.

\subsection{Contributions to Theory}

RQ1: What are the main barriers to smooth implementation of digitalisation in banking?

From December 2019 to March 2020, a total of 32 semi-structured interviews were conducted with board members in banking. This study contributes to the literary expansion and the first definition of barriers to implementation of digitalisation in the banking market, which can be used for further research. A total of 63 codes were worked out according to Mayring's method, which form the preliminary main category set (see Appendix A). Due to the complexity of the analytical approach, only the steps following the generalisation of Mayring's method can be presented in the Appendix A. Detailed representations are not feasible due to graphical limitations. Corresponding definitions for the respective sub-barriers enable interpretation for future analyses. Main categories represent the superordinate classification level of the respective sub-category set, but are not characterised by an independent definition. Table 5 presents a summary of the set of categories that represent the main barriers to smooth implementation of digitalisation in banks, with respect to savings and the cooperative bank sector.

Table 5. Category summary.

\begin{tabular}{cc}
\hline Main Category & Number of Sub-Categories \\
\hline Benefits & 1 \\
Customer & 11 \\
Employee & 8 \\
Knowledge and Product & 4 \\
Market & 4 \\
Participation & 2 \\
Strategy and Management & 25 \\
Technology and Regulation & 8 \\
\hline
\end{tabular}

Source: Authors' own representation.

\subsection{Contributions to Practice}

RQ2: What are the "best practices" that are applicable in the implementation of digitalisation process?

For this study, 34 interviews were conducted with bank executives on the topic of digitalisation in the banking sector, with emphasis on the digitalisation of their own banks. A total of 32 interviews were identified as valid for the case-analytical approach in this chapter and were used accordingly for the practical interpretation of the study results. A similar approach to interpreting interviews had already been followed in an earlier publication by Diener and Špaček [90]. The bank managers were not asked about the problems they encountered in practice, but rather about their best-practice approaches to digital transformation. All interview partners were asked the same question for reasons of consistency.

What concrete measures have you/has your bank taken in the past to keep pace with digital competition and the changing pace of digitalisation? (Interview Question 10)

This question was deliberately kept general in order to give respondents the greatest possible scope for answering it. As this is also highly sensitive information, data protection had to be guaranteed and data protection rules had to be respected. In particular, the respondents insisted on anonymity. Due to their professional status, the interviewees 
quoted in this chapter explicitly stressed the wish not to be named or quoted in person. The same applies to their banks. Official interview material would require explicit permission by the bank before publication, which is not feasible in the context of this scientific analysis and would lead to biased answers. For this reason, the original transcripts of the interviews were used for this study and the respondents were only mentioned anonymously. The interviewees are therefore only referred to as "Interviewee" in the following.

The analysis of the interviews showed that all decision-makers were generally aware of digital change in banking and particularly aware of digital changes and the issue of digitalisation in their own banks. Banks are even hiring a board member specifically focused on digitalisation. "[ . . ] many banks are now hiring a Chief Digital Officer. There is a new position that was actually created" (Interviewee 20-Section 49).

This move towards more digital orientation and new approaches to customer service may lead to a complete shift in personnel structures in some departments. As a result, employees no longer work in the bank branches that have been known for decades, but are now able to offer a full range of services independently of their geographical location. This development takes into account the efficiency concept of the branch and the increasing competition, which, according to the assessment of the interviewees, will lead to farreaching structural changes within the banking sector in the future. However, with constant digital development, the question arises how a branch without customer traffic can be physically maintained in the future and what justifies the maintenance of cost-intensive branches. These descriptions from the interviewees indicate that they actively try to react to corresponding market developments within the scope of what is economically feasible and to develop further. One interviewee confirmed that his bank is actively addressing new trends and issues in order to take them into account in its corporate focus. "In particular, we are very active in the field of trend scouting and in identifying and evaluating the strategic relevance of various trends and technologies. [ . . . ] We have an innovation lab where we do trend scouting and observe about 170 trends and technology duration" (Interviewee 26-Section 29). Another manager emphasised that the integration of employees into the thinking process of change is fundamental and that this should be secured and promoted by the necessary freedom of thought and continuous exchange between employees and management. "[ . . ] we have set up a room of ideas where every employee, from trainee to board member, can say: 'I have a cool idea and would like to present it.' There is a group of supporters who-for example, when trainees come, are perhaps not yet very good at presenting-support the employees in creating a small presentation. And then they can present directly to the board of directors" (Interviewee 14-Section 139).

The interviews also revealed that cooperation with external partners plays an important role in the further development of banks and that cooperation within the banking association is fundamental, but also leads to a slow-down due to increased structural complexity. Banks today cooperate with partners such as university institutions, which support them in the further and new development of applications, as well as future strategies, and provide them with the necessary know-how for digital corporate transformation. In particular, the participation of the target group at the university level, such as the actual developers of the applications, helps to align and develop the bank's range of products and services to the needs of the customer, which contributes to a tailor-made fit of banking solutions-at least for the younger generation of customers. One interviewee mentioned: "In two years we have made a lot of progress in this area, and in the meantime we have widened the channels. In other words, we have provided a chat solution to improve customer contact. At the same time, a video service consulting branch is also starting this year. This means a branch in which there are no employees any more, but the branch is looked after centrally from the customer dialogue centre with extended service times from 08:00 to 18:00. [ . . . What we have achieved for ourselves is to work together with universities, often here in the region, to design things in a way that is appropriate for the target group. [...] Together with a university, we have developed an app in the youth market" (Interviewee 17-Section 79).

The digital transformation in banking is progressing at an ever-increasing pace. Far away from interface requirements forced by regulatory laws, just a few institutions are 
creating application interfaces on their own initiative, which enable them to integrate innovative business models and/or products. "We also support via the Banking-API (Application Programming Interface) such innovations as Google Assistant or Alexa and many other things" (Interviewee 21-Section 14). However, the main focus is still on realising stronger networking, which ultimately benefits both the banks themselves and the bank customers. It enables a more comprehensive range of products and services. Digitalisation, in this context, implies not only the development of internal approaches and ideas, but also the intended cooperation with other credit institutions, external partners, and FinTechs, which is to be enabled and realised via application programming interfaces " $[\ldots]$ so that we can also integrate our technical processes, which we have for product closures and transactions, into third-party platforms in order to network more closely with each other" (Interviewee 21Section 14). It seems obvious that the management has recognised digital transformation and is focusing on it accordingly in its banking activities.

In order to adopt and pursue new digital approaches, far from merely perceiving trends, managers are responding by elaborating in detail practical approaches that will facilitate and fundamentally enable future digital implementation. This process, however, requires the availability of appropriate resources, as implementation is ultimately only made possible by making them available. On this point, a large discrepancy is evident between small, medium, and large banking institutions-major challenges of a possible holistic digitalisation can be advanced together in a more targeted way. For a small bank, topics such as "quantum computing", which could be highly important within the next 10 to 15 years, simply cannot be tackled today from a financial point of view, since the costs exceed the available resources. It is crucial, though, that banks, regardless of their size, systematically address tomorrow's digital issues today, so that they can "have the necessary know-how to deal with them proactively at the appropriate time. There is no doubt that banks definitely want to know what is happening and have a clear opinion on it" (Interviewee 26-Section 29). Knowledge and the ability to react are important here; "[ ... ] one has to be familiar with the complex issues in good times, otherwise one cannot react accordingly" (Interviewee 26-Section 33).

Today's bank management attributes an important role model to the employees, as they implement digitalisation in the company in a targeted manner and bring it closer to the customer. It is, therefore, essential that employees are informed regarding technological applications and know how to apply them properly and safely. Employees and customers have to be taken along and introduced to the technology. Since this has to be done holistically and not only for specific target groups of customers and employees, it is important to differentiate between individual groups of both customers and employees and their individual age structures to introduce them to the technology in a targeted manner. Specific educational programmes and events for customers and employees are being introduced in banks to facilitate the implementation of digital approaches and, ultimately, bank digitalisation, as well as to enhance the acceptance and integration of employees and customers. "Not long ago, we held a digitalisation fair just for our employees. [...] It cost a lot of money. So we did it professionally, with professional providers. Just to show our employees what's available. There were various stands with different focal points. So that you have topics that you can understand. Online brokers were there. There were $3 D$ glasses where you can look at a house that we sell. And things like that. A multitude of things. And for us it is just important to take the employees with us. They know that digitalisation is destroying jobs [...] the trade fair has certainly contributed to the fact that the mood in our company is quite good at the moment. So the employees are going with us. One of the main problems is that some of our employees don't deal with things privately" (Interviewee 27/28-Section 47).

According to the executive management, internal experts prove to be of great value, as they can deal with a specific digitalisation topic, communicate it to the respective individuals, and support them accordingly. "For example, we have set up a programme with other partners, called Digital-Tiger, where we have specially trained one employee in each market area as a Digital-Tiger (an expert). He then serves as a multiplier, which also serves to encourage 
the employees more [ ... W We actually have seven experts in the entire company, e.g., in the corporate customer area and real estate centre. There is an expert in every branch office who is regularly trained. Then, in turn, he transfers the already existing knowledge and new knowledge or new products to the employees" (Interviewee 13-Section 45). This development indicates that the relevance of a topic is becoming increasingly important and that the necessary financial and humanitarian resources are being mobilised in order to pursue and promote topics internally. However, this is, without question, highly dependent on the individual perception, understanding, and acceptance of the management on the topic as well as on the general financial situation of each individual bank. It also depends on the availability of trained employees, the actual specialists, as people have to be mobilised for (change) projects and show the will to change and participate. In addition, the respective corporate "change culture" within the bank is crucial, as employees also have to be prepared to be led by specialists and managers and should not be completely opposed to new methods and change. Only through such a culture can new topics or digitalisation be realised. New topics and, ultimately, digitalisation can only be realised holistically and effectively if these framework conditions are met. "In a traditional company like ours, with people who are very security-oriented and very conservative in their attitudes, this is a challenge in itself. That means accompanying this human resource development or mentality development culture, development process" (Interviewee 17-Section 29).

Furthermore, the technological framework conditions have to be in place for digital change and have to meet certain prerequisites, but this still fails because of problems such as IT infrastructure, both on the bank side and on the side of the infrastructure provided by the state. "You first have to create the basis [...] so there's a big hurdle of servers and WLAN or LAN speed. You first have to create this for every branch in principle, for every stationary location [...]. And that is a big challenge, all the more in rural areas. [...] The wires have not been laid in the past. Twenty years ago, no one needed a strong internet connection. So now the question is: Is it possible from a constructional and technical point of view? What does it cost? In principle, that's where it starts" (Interviewee 10-Section 49). In order to be able to address a complex topic such as digitalisation in an individually customer-oriented way, banks are currently still very much dependent on the cooperative associations and linked to them on a technological level. There is less focus on independent in-house innovation development, which could enable a more tailored transformation on its own. Nevertheless, there are banks that have dedicated themselves to the topic. "We started a few years ago, for example, to set up an Innovation Lab in our company. [...] Then, of course, we also started to adopt the new technologies and implement agile concepts in our company. This led to the fact that at some point people said that we wanted to create a whole programme and ultimately digitalise the whole company" (Interviewee 31-Section 57). This approach presupposes the availability of the resources necessary for implementation, but supports the independent development of the corporate identity and can, ideally, address the needs of customers and employees in a precise manner at the same time.

The approaches discussed above represent a variety of elements that, from a managerial perspective, are or can be seen as fundamental for a holistic, fast, and tailor-made digital transformation and at least promote it significantly.

Multiple measures are being taken to promote digital transformation within banks. These include, in particular, measures to introduce employees and customers to new digital processes and technology in general in order to integrate these two groups into the process of transformation. However, funding that is sustainable at the technological level and that leads to a faster technological transformation cycle or to the reduction of regulatory research or its process-optimised (over)fulfilment is only addressed in a limited, global manner and does not address specific issues.

The measures currently taken and the managers' descriptions indicate that technological integration itself seems to be the most effective tool for successful change. This way of thinking is shared by large and small banking institutions alike. It is apparent, however, that small banks expect membership in an association to be the factor that determines 
success in further development, and that technological solutions should primarily be made available centrally. However, independent development and implementation of digital approaches are hardly taken into account in small-to-medium-sized institutions (SMEs), and are sometimes not even considered for reasons such as affiliation with an association or the requirement for excessive expenditure. This goes against the self-development approach of applications based on open-source solutions, which can now be realised at low cost and could be used, at least regionally, if an appropriate interface were provided.

These considerations, therefore, contrast with the understanding of management and their arguments against self-development. "Simple issues have to be implemented quickly and directly. Of course, this currently overwhelms many employees. But this will change slowly and continuously in three or four years. Open source, for example, now offers so many possibilities that you can virtually develop software in a very short time. The cost driver has to be assessed quite differently today than 15 years ago. The reason for this is that IT development is now possible in days, weeks, and months and no longer in years. Until then, banks often had three- to five-year development plans" (Interviewee 33-Section 20).

If one considers the prevailing view of the current management, however, it is primarily the situation of a resource-related discrepancy between small and large banks that weakens rural banking structures and increasingly drives these small banks into an association structure and, thus, into increased dependency. Nevertheless, this view cannot be supported on the basis of the above-mentioned low-cost technological approaches, such as open-source technologies and an ever more widespread API and interface structure.

Measures such as staff and customer fairs on technology topics, specially trained staff who supervise digital topics, creative rooms, and innovation labs are approaches that can be implemented efficiently and in a resource-saving manner within banks and can contribute to direct development. The innovation lab, admittedly, is associated with volatile costs, depending on the particular use and programmatic design, which should be carefully examined. However, the increasingly standardised interface programming, APIs, and open-source approaches can also improve and optimise the entire internal bank process structure, as an accelerated and targeted integration of applications of new offers is ultimately made possible. The first approaches mentioned are, from a creative point of view and a resource-conscious leadership approach by the management, especially easy to implement and equally easy to realize.

With regard to the findings on "Complex technology and increased regulation", there is a need for banks to catch up in order to implement digitalisation in a competitive and sustainable way so that they can become even more digital in the future. A few individual approaches by banks demonstrate that there are technologies that allow developments to take place at low cost. "Open source offers many new potentials" (Interviewee 33-Section 60). The only thing that needs to be done is to find and attract the appropriate IT staff who are specifically trained to deal with these issues. "In order to develop digital business models that represent a unique selling proposition, not only central but also decentralised IT know-how is needed. Central IT development alone will not be sufficient in the future" (Interviewee 33-Section 17).

\section{Conclusions and Further Research}

In this study, qualitative findings were combined with best-practice approaches from the banking sector with regard to digitalisation and the barriers that arise in this context. Here, for the first time, qualitative derivations were made that require further investigation. The interest of the interview participants, as well as their voluntary and open-minded participation in the study, once again underlines the importance of this explorative approach. The results also show a wide-ranging, still-young field of research, which needs further attention. This is underlined by the problematic nature of the literature analysis and the need to draw on derivations from sectors with similar challenges. Based on the present results, it is suggested that the identified transformation/implementation barriers and the reasons for a prevailing discrepancy between perceived and actual responses to digitalisation should be analysed and scrutinised in detail in further research. It could be 
the case that the large number of barriers identified limits the possibilities for interpretation, so a further reduction of the subcategories could be considered. There is also the possibility that other influencing variables can be identified.

In addition, management perceptions of the scale of barriers could be studied in more detail and practical transformation approaches could be analysed in more depth. Studies could also focus on examining banks and their management more deeply in terms of their approaches to digital transformation and identify further best-practice approaches. Furthermore, it is recommended that, in future studies, the results should be examined with a larger number of participants in all methodological approaches to maximise the possibility that further recommendations can be derived on the basis of existing bank structures or their business models. The differences between individual banks could provide insights to obtain more detailed results on barriers to implementing digitalisation.

The development of a comprehensive normative model for scientific and sectoral enrichment would be desirable. It would also be advisable to quantitatively record individual correlations between main and sub-barriers and to implement sustainable aspects in the research approach. An additional topic for further research is the study of the impact of digital transformation on the sustainable growth of banking organisations. This topic does not seem to be addressed in sufficient depth; a thorough investigation of the preconditions for digital transformation, which are prerequisites for sustainable development, is crucial. The development of a questionnaire is indispensable for the implementation of further quantitative studies so that analyses at the main barrier level or even studies of sub-barriers can be enabled. These further approaches could lead to the enrichment of not only the investigation of digital transformation, but also the banking sector in general, and could enable further industry studies, including in other industry sectors.

Author Contributions: Conceptualization, F.D.; methodology, F.D.; formal analysis, F.D.; investigation, F.D.; resources, F.D.; data curation, F.D.; writing-original draft preparation, F.D.; writingreview and editing, F.D.; supervision, M.Š. All authors have read and agreed to the published version of the manuscript.

Funding: No external funding.

Institutional Review Board Statement: Not applicable.

Informed Consent Statement: Informed consent was obtained from all subjects involved in the study.

Acknowledgments: We would like to thank all interview partners for their open participation.

Conflicts of Interest: The authors declare no conflict of interest.

Appendix A

\begin{tabular}{|c|c|c|c|}
\hline Main Category & Sub-Code & Code Description & $\begin{array}{l}\text { Number of } \\
\text { Sub-Codes }\end{array}$ \\
\hline Benefits & $\begin{array}{l}\text { No public } \\
\text { funding }\end{array}$ & $\begin{array}{l}\text { No public funding is known or available for the (further) development of } \\
\text { banking technologies. It is assumed that banks have the necessary financial } \\
\text { resources to implement digital transformation themselves and, therefore, do } \\
\text { not need support. }\end{array}$ & 27 \\
\hline \multirow{5}{*}{ Customer } & Customer & Customers have concerns and reject digitalisation in general. & 1 \\
\hline & Acceptance & $\begin{array}{l}\text { Customer acceptance and trust in the application/technology varies from person } \\
\text { to person and is an essential factor that has to be created and considered. }\end{array}$ & 18 \\
\hline & State of the art & $\begin{array}{l}\text { More and more is expected from and offered to the customer. However, } \\
\text { customers are not always able to use the technology to its full extent. }\end{array}$ & 6 \\
\hline & Age structure & $\begin{array}{l}\text { Based on their different ages, customers have different knowledge and } \\
\text { expectations towards digital technology and possibilities to use it. }\end{array}$ & 13 \\
\hline & $\begin{array}{l}\text { Usage } \\
\text { behaviour }\end{array}$ & $\begin{array}{l}\text { The customer's behaviour is changing in the sense that he/she is evolving } \\
\text { from an analogue to a digital customer. Services, especially digital ones, } \\
\text { should be available at all times, but old services should be retained as well. }\end{array}$ & 12 \\
\hline
\end{tabular}




\begin{tabular}{|c|c|c|c|}
\hline Main Category & Sub-Code & Code Description & $\begin{array}{l}\text { Number of } \\
\text { Sub-Codes }\end{array}$ \\
\hline \multirow{6}{*}{ Customer } & Expectations & $\begin{array}{l}\text { Customer expectations are very diverse. On the one hand, some } \\
\text { expect the permanent availability of technology and, at the same } \\
\text { time, the possibility to continue to use personal consultants. On the } \\
\text { other hand, others do not expect multi-channel offers. Both, } \\
\text { however, are characterized by the expectation of security. }\end{array}$ & 28 \\
\hline & Knowledge & $\begin{array}{l}\text { Today's customers are often well informed, but this knowledge as } \\
\text { a whole is very heterogeneous, though increasing. }\end{array}$ & 3 \\
\hline & $\begin{array}{l}\text { Non-existing } \\
\text { knowledge }\end{array}$ & $\begin{array}{l}\text { Customers are not informed about the existing possibilities and } \\
\text { are not familiar with banking and technology issues. }\end{array}$ & 5 \\
\hline & Existing knowledge & $\begin{array}{l}\text { The customers have knowledge and are well informed. Knowledge is } \\
\text { acquired online. For certain topics, no consultants will be needed in } \\
\text { the future. }\end{array}$ & 2 \\
\hline & Customer proximity & $\begin{array}{l}\text { Digitalisation and the resulting consequences of branch closures } \\
\text { lead to a minimization of personal customer contact. }\end{array}$ & 12 \\
\hline & Switching behaviour & $\begin{array}{l}\text { Digitalisation leads to a reduction in customer retention and } \\
\text { loyalty. Customers become more open-minded for new things and } \\
\text { "everything from one single source" is less important than before. }\end{array}$ & 9 \\
\hline \multirow{8}{*}{ Employee } & Employee & $\begin{array}{l}\text { Employees will be needed less in the future. However, digital } \\
\text { transformation is not possible without a minimum number of } \\
\text { employees, who, in turn, can only be maintained with appropriate } \\
\text { compensation (war for talents). Existential worries, fears, and } \\
\text { inhibitions arise, which are individually pronounced for } \\
\text { each employee. }\end{array}$ & 14 \\
\hline & Flexibility & $\begin{array}{c}\text { Employees are often overwhelmed by digitalisation and reach } \\
\text { their limits. In the future, they need to be flexible and fast enough } \\
\text { to adapt to and deal with new developments. }\end{array}$ & 9 \\
\hline & Acceptance & $\begin{array}{l}\text { Employees do not show acceptance at the beginning of a change } \\
\text { and often reject the new at first. Employees have to be involved in } \\
\text { the change process and learn how to deal with digitalisation and } \\
\text { corresponding innovations. It is fundamental that employees } \\
\text { should use software and hardware themselves. }\end{array}$ & 20 \\
\hline & Qualification & $\begin{array}{l}\text { Relevant qualifications for employees are not sufficiently available, } \\
\text { and this turns out to be a disadvantage for the implementation of } \\
\text { complex digital topics and the general digital change in banks. } \\
\text { Qualifications will have to be adapted in the future. }\end{array}$ & 16 \\
\hline & Availability & $\begin{array}{l}\text { There are not enough people on the market to fill open IT } \\
\text { vacancies for a decent salary and, ultimately, to work on digital } \\
\text { issues and enable digital transformation. }\end{array}$ & 15 \\
\hline & Friendliness & Employee friendliness could be improved. & 1 \\
\hline & Age structure & $\begin{array}{l}\text { The age structure in banks will change in the future. Increasingly } \\
\text { obsolete employees will lead to the need for digitalisation. It is } \\
\text { assumed that the majority of predominantly older employees will } \\
\text { slow down or even prevent change. Young people, on the other } \\
\text { hand, will not, as they have grown up with digital media } \\
\text { and processes. }\end{array}$ & 10 \\
\hline & Transparency & $\begin{array}{l}\text { Digitalisation leads to increased employee and process } \\
\text { transparency, which, in turn, is feared by employees. }\end{array}$ & 3 \\
\hline \multirow{3}{*}{$\begin{array}{l}\text { Knowledge and } \\
\text { Product }\end{array}$} & $\begin{array}{l}\text { Product and Bank } \\
\text { complexity }\end{array}$ & $\begin{array}{l}\text { The banking world and its range of products and services is } \\
\text { becoming increasingly complex. Here, the complexity of the offer } \\
\text { determines whether analogue or digital consulting services are } \\
\text { used. Customers often obtain information online and then contact } \\
\text { their bank offline. Complex topics can currently only be digitally } \\
\text { modelled to a limited extent. However, numerous simple } \\
\text { processes are also still offered exclusively in analogue form. }\end{array}$ & 9 \\
\hline & $\begin{array}{l}\text { Human uncertainty } \\
\text { factor }\end{array}$ & $\begin{array}{l}\text { Man-made mistakes lead to widespread effects in a centrally } \\
\text { organized (IT) infrastructure. Digitalisation can increase } \\
\text { transparency and minimise error, but it can also promote them } \\
\text { and create uncertainty. }\end{array}$ & 2 \\
\hline & $\begin{array}{l}\text { Experts } \\
\text { (internal) }\end{array}$ & $\begin{array}{l}\text { Experts on digital issues are (still) available internally to a certain } \\
\text { extent and are fundamental for digital transformation in banking. } \\
\text { Decentralised digitalisation will require more qualified personnel } \\
\text { in the future. }\end{array}$ & 19 \\
\hline
\end{tabular}




\begin{tabular}{|c|c|c|c|}
\hline Main Category & Sub-Code & Code Description & $\begin{array}{l}\text { Number of } \\
\text { Sub-Codes }\end{array}$ \\
\hline $\begin{array}{l}\text { Knowledge and } \\
\text { Product }\end{array}$ & $\begin{array}{l}\text { Experts } \\
\text { (external) }\end{array}$ & $\begin{array}{l}\text { External (digital) experts/consultants are available to banks in } \\
\text { large numbers. Universities also support banks. Both are available } \\
\text { to banks for digitalisation projects if required. External } \\
\text { consultants usually charge high costs. }\end{array}$ & 23 \\
\hline \multirow{4}{*}{ Market } & Market situation & $\begin{array}{c}\text { Investments in digitalisation require capital. The current market } \\
\text { situation poses challenges for banks: Only lower earnings are } \\
\text { being generated due to the interest rate policy. }\end{array}$ & 8 \\
\hline & Market uncertainty & $\begin{array}{l}\text { The results of the digitalisation process cannot be measured yet. } \\
\text { Future market developments and uncertain success are } \\
\text { determined by the customer. Banks are concerned about the right } \\
\text { corporate positioning, as there are few sustainable approaches. }\end{array}$ & 11 \\
\hline & Market power & $\begin{array}{l}\text { The current market situation poses challenges for banks. With } \\
\text { their increased market power, they can block competitors and thus } \\
\text { defend their position. }\end{array}$ & 2 \\
\hline & $\begin{array}{l}\text { Market/competitive } \\
\text { pressure }\end{array}$ & $\begin{array}{l}\text { The increased competitive pressure due to technical and } \\
\text { market-driven developments will increase in the future, not only } \\
\text { between FinTechs and banks, but also between banks themselves. }\end{array}$ & 22 \\
\hline \multirow[t]{2}{*}{ Participation } & Employee involvement & $\begin{array}{l}\text { Employees are actively involved in digitalisation issues by } \\
\text { management and are encouraged to develop and implement their } \\
\text { own ideas. The management creates the appropriate space for this. } \\
\text { In the end, they can (better) identify themselves with the } \\
\text { transformation and become a part of it. It is fundamental that } \\
\text { employees should apply the technology themselves. }\end{array}$ & 18 \\
\hline & Customer integration & $\begin{array}{l}\text { Customers are seen as partners. They are actively involved in } \\
\text { development and in ongoing processes. By involving them at an } \\
\text { early stage, their needs can be taken into account and they can } \\
\text { actively participate in shaping the process. }\end{array}$ & 15 \\
\hline \multirow{9}{*}{$\begin{array}{c}\text { Strategy/ } \\
\text { Management }\end{array}$} & $\begin{array}{c}\text { FinTechs } \\
\text { (partners/ } \\
\text { (non-)competitors) }\end{array}$ & FinTechs can be both partners and competitors. & 5 \\
\hline & FinTech (partners) & $\begin{array}{c}\text { FinTechs have become much more like partnership-based } \\
\text { companies (partners) that want to advance their own ideas } \\
\text { through cooperation and are looking for banks to support them } \\
\text { in this. }\end{array}$ & 8 \\
\hline & $\begin{array}{c}\text { FinTech } \\
\text { (non-competitors) }\end{array}$ & $\begin{array}{l}\text { Banks will continue to exist in the future and will be increasingly } \\
\text { digitalised through constant development. FinTechs should be } \\
\text { seen as a complementary approach and not as a competitor that } \\
\text { poses a threat to banks. }\end{array}$ & 10 \\
\hline & FinTech (competitors) & $\begin{array}{c}\text { Competition is increasing in the financial industry and FinTechs } \\
\text { are now seen as competitors, forcing banks to react and bring their } \\
\text { own digital solutions to the market. }\end{array}$ & 22 \\
\hline & $\begin{array}{l}\text { Banks want to } \\
\text { cooperate }\end{array}$ & $\begin{array}{l}\text { Banks seek proximity to external FinTechs or try to become active } \\
\text { themselves in the FinTech sector with their own developments. } \\
\text { These young companies very often offer innovative solutions: } \\
\text { Accordingly, banks would like to cooperate with them in order to } \\
\text { develop themselves further. }\end{array}$ & 23 \\
\hline & $\begin{array}{l}\text { Banks will not/cannot } \\
\text { cooperate }\end{array}$ & $\begin{array}{l}\text { Banks are unwilling or unable to cooperate with FinTechs for } \\
\text { organisational or interface reasons. The dominant positioning of } \\
\text { banks is intended to make market access more difficult } \\
\text { for FinTechs. }\end{array}$ & 6 \\
\hline & $\begin{array}{l}\text { Dependence on } \\
\text { providers }\end{array}$ & $\begin{array}{l}\text { Banks and FinTechs need customers and their data. There is a risk } \\
\text { of dependence on external providers and loss of control over their } \\
\text { own business. Only in exceptional cases is cooperation favoured. }\end{array}$ & 5 \\
\hline & $\begin{array}{l}\text { Reaction to } \\
\text { market } \\
\text { development }\end{array}$ & $\begin{array}{l}\text { Banks are reacting to market and competitive situations and are } \\
\text { trying to keep up with the latest developments in analogue and } \\
\text { digital services. They rely on systematic development, which is } \\
\text { implemented with the help of internal innovation management. } \\
\text { This approach is embedded in their strategy. }\end{array}$ & 26 \\
\hline & $\begin{array}{l}\text { Complex corporate } \\
\text { structure and multiple } \\
\text { interests }\end{array}$ & $\begin{array}{l}\text { In a large and differentiated corporate structure, banks have to } \\
\text { meet multiple and often complex customer needs of different age } \\
\text { groups. Expectations of permanent analogue and simultaneous } \\
\text { digital accessibility increase the complexity of today's } \\
\text { banking business. }\end{array}$ & 16 \\
\hline
\end{tabular}




$\begin{array}{ccc}\text { Main Category } & \text { Sub-Code } & \begin{array}{c}\text { Code Description } \\ \text { Sub-Codes }\end{array} \\ \text { (Re)structuring } & \begin{array}{c}\text { Banks will have to restructure themselves in the future and } \\ \text { rethink both new and traditional approaches. This requires } \\ \text { change processes that are appropriate to the bank's size. } \\ \text { Restructuring leads to obstacles / resistance among employees and } \\ \text { customers, which are very much shaped by individual humanity. }\end{array} \\ \begin{array}{c}\text { Reputation } \\ \text { worries }\end{array} & \begin{array}{c}\text { Banks are concerned about negative reputational consequences if } \\ \text { the cooperation with or participation in FinTechs fails. }\end{array} \\ \begin{array}{c}\text { Risk aversion } \\ \text { Managers avoid the risks associated with new issues such } \\ \text { as digitalisation. }\end{array} & \begin{array}{c}\text { Manks often organise themselves in a central association structure } \\ \text { and can thus position themselves more strongly as a group. } \\ \text { However, this leads to dependencies on central services and } \\ \text { technologies and limits decision-making options. The } \\ \text { Organizational } \\ \text { dependency }\end{array} \\ \begin{array}{c}\text { individuality of each bank is lost, as organisations dictate the } \\ \text { corporate guidelines. }\end{array}\end{array}$
corporate guidelines. tructures of banks within a banking group, the speed of reaction of an institution depends strongly on centralised developments.

Digitalisation is an essential part of the current strategy of financial institutions. One is aware that the future of the financial

Digitalisation strategy markets will be strongly influenced by digital topics. The basic prerequisite for sustainable development in the future must be created today.

Transparency $\quad$ Digitalisation leads to transparent markets and products. Offers choose the most suitable solution.

Strategy/ Management
Corporate culture/tradition
Banks are shaped by the historical corporate culture and tradition that has been established over many decades. This is precisely what determines the processes and the orientation of banks.

Young customers, in particular, are questioning this. Management must rethink and a change in leadership from old to young is required.

The management sees the importance of the topic of digitalisation and takes the need for further development and its influence. In their opinion, digitalisation will contribute to process optimization and automation in the future. It is assumed that banks are on the right track, but only a small part of what is possible has been implemented to date.

perception

Resources not available

Resources are not available for digital in-house and further development of products and approaches.

\begin{tabular}{cc}
\hline $\begin{array}{c}\text { Resources } \\
\text { limited }\end{array}$ & Resources for digital developments are limited. \\
\hline Resources available & $\begin{array}{c}\text { Resources are available for further digital development or are } \\
\text { mobilized if the company positions itself digitally accordingly. }\end{array}$ \\
\hline Resource allocation & $\begin{array}{c}\text { Resources must be allocated within established structures in such } \\
\text { a way that they finance existing and new approaches adequately } \\
\text { and that institutions do not fall behind. Misallocation can slow } \\
\text { down important developments such as digitalisation. }\end{array}$ \\
\hline Costs & $\begin{array}{c}\text { Digitalisation and the infrastructure required for it is associated } \\
\text { with high costs, which a bank has to finance independently. }\end{array}$ \\
& $\begin{array}{c}\text { Investment decisions are closely monitored, as they are ultimately } \\
\text { borne by the bank's customers. Potentials such as cost savings in a } \\
\text { corporate structure can be achieved through digitalisation. The } \\
\text { costs can be seen as an obstacle. }\end{array}$ \\
\hline $\begin{array}{c}\text { The decision-making process is time-consuming. Many internal } \\
\text { Decision-making } \\
\text { process }\end{array}$ & $\begin{array}{c}\text { and external interests have to be taken into account. Additionally, } \\
\text { decisions are influenced by umbrella organisations. The boards of } \\
\text { directors of banks still make their decisions largely independently, } \\
\text { but the basis is increasingly integrated to create greater acceptance } \\
\text { for change. }\end{array}$ \\
\hline
\end{tabular}




\begin{tabular}{|c|c|c|c|}
\hline Main Category & Sub-Code & Code Description & $\begin{array}{l}\text { Number of } \\
\text { Sub-Codes }\end{array}$ \\
\hline $\begin{array}{l}\text { Strategy/ } \\
\text { Management }\end{array}$ & Disruption & $\begin{array}{l}\text { Banks face technological developments and the associated risk of } \\
\text { disruption in an increasingly fast and competitive market. They } \\
\text { have to adapt to technologies and, at the same time, to the pace of } \\
\text { digitalisation, without losing their own identity, in order to } \\
\text { survive and remain competitive. }\end{array}$ & 15 \\
\hline \multirow{8}{*}{$\begin{array}{l}\text { Technology and } \\
\text { Regulation }\end{array}$} & Useability & $\begin{array}{l}\text { Usability is essential for customers in digital applications. } \\
\text { Customers must be taken into account-for certain customer } \\
\text { groups, usability is not a given. }\end{array}$ & 3 \\
\hline & Technical effort & $\begin{array}{l}\text { The technical and cost-related expenditures for banks for the new } \\
\text { and further development and adaptation of solutions are very } \\
\text { high. This makes digitalisation more difficult, which ultimately } \\
\text { becomes an obstacle. }\end{array}$ & 13 \\
\hline & $\begin{array}{l}\text { Regulatory } \\
\text { obstacles }\end{array}$ & $\begin{array}{l}\text { Regulatory requirements must be met by banks by law. This } \\
\text { confronts them, from an internal and external perspective of } \\
\text { further development, with major obstacles that slow } \\
\text { down digitalisation. }\end{array}$ & 21 \\
\hline & $\begin{array}{l}\text { Data } \\
\text { protection/security and } \\
\text { integrity }\end{array}$ & $\begin{array}{l}\text { Banks and FinTechs are becoming more and more networked, and } \\
\text { customers are becoming more and more transparent, particularly } \\
\text { through free access and exchange of data. In this context, data are } \\
\text { subject to special protection requirements, which poses a } \\
\text { challenge for both banks and FinTechs. This is slowing down } \\
\text { digitalisation. Banks are subjectively more strongly monitored } \\
\text { and are more in public focus than FinTechs. }\end{array}$ & 18 \\
\hline & $\begin{array}{l}\text { Implementation } \\
\text { difficulties }\end{array}$ & $\begin{array}{c}\text { The implementation of new processes and technologies in banks, } \\
\text { taking into account legal requirements and the growing IT } \\
\text { infrastructure, causes implementation problems of digital } \\
\text { approaches and slows down or even completely inhibits } \\
\text { digitalisation in banking. }\end{array}$ & 13 \\
\hline & Public infrastructure & $\begin{array}{l}\text { The public infrastructure does not meet the requirements for } \\
\text { comprehensive digitalisation of banks. }\end{array}$ & 6 \\
\hline & $\begin{array}{l}\text { Outdated IT } \\
\text { infrastructure }\end{array}$ & $\begin{array}{l}\text { The demands on banking IT are increasing together with the } \\
\text { speed of technology cycles and the associated technological } \\
\text { developments. Banks will never be able to keep up with the latest } \\
\text { developments. Legacy IT infrastructures place limits on } \\
\text { digitalisation in banks. }\end{array}$ & 7 \\
\hline & $\begin{array}{l}\text { State of the } \\
\text { art/integration (today) }\end{array}$ & $\begin{array}{c}\text { Centrally provided technology and corresponding interfaces are } \\
\text { not sufficiently developed to allow technical approaches to be } \\
\text { integrated into banks without problems and to enable } \\
\text { holistic digitalisation. }\end{array}$ & 11 \\
\hline
\end{tabular}

\section{References}

1. Türkmen, E.; Soyer, A. The Effects of Digital Transformation on Organizations. In Handbook of Research on Strategic Fit and Design in Business Ecosystems: Advances in E-Business Research; IGI Global: Hershey, PA, USA, 2020; pp. 259-288. [CrossRef]

2. Hess, T.; Matt, C.; Benlian, A.; Wiesböck, F. Options for Formulating a Digital Transformation Strategy. MIS Q. Exec. 2016, 15, 123-139.

3. Ivančić, L.; Stjepic, A.-M.; Vugec, D.S. Mastering digital transformation through business process management: Investigating alignments, goals, orchestration, and roles. J. Entrep. Manag. Innov. 2020, 16, 41-73. [CrossRef]

4. Ismail, M.H.; Khater, M.; Zaki, M. Digital Business Transformation and Strategy: What Do We Know So Far? Working Paper University of Cambridge; University of Cambridge: Cambridge, UK, 2018.

5. Westerman, G.; Bonnet, D.; McAfee, A. The Nine Elements of Digital Transformation. MIT Sloan Manag. Rev. 2014, 55, 1-6.

6. Aydalot, P.; Keeble, D. High Technology Industry and Innovative Environments, 1st ed.; Routledge: London, UK, 2018.

7. Cohen, B.; Amorós, J.E.; Lundy, L. The generative potential of emerging technology to support startups and new ecosystems. Bus. Horiz. 2017, 60. [CrossRef]

8. Li, L.; Su, F.; Zhang, W.; Mao, J.-Y. Digital transformation by SME entrepreneurs: A capability perspective. Inf. Syst. J. 2017, 28, 1-29. [CrossRef]

9. Deutsche Bundesbank. Zahlungsverhalten in Deutschland-Eine empirische Studie über die Auswahl und Verwendung von Zahlungsinstrumenten in der Bundesrepublik Deutschland. 2009. Available online: https://www.bundesbank.de/ resource/blob/599956/4d15527da87c104926f9ad8c5a53707a/mL/zahlungsverhalten-in-deutschland-2009-data.pdf (accessed on 10 September 2019).

10. Deutsche Bundesbank. Zahlungsverhalten in Deutschland 2011-Eine empirische Studie über die Verwendung von Bargeld und unbaren Zahlungsinstrumenten. 2012. Available online: https://www.bundesbank.de/resource/blob/663302/8b1c7f5a6407b2 1aac71dd41cef8bbd2/mL/zahlungsverhalten-in-deutschland-2011-data.pdf (accessed on 10 September 2019). 
11. Deutsche Bundesbank. Zahlungsverhalten in Deutschland 2014—Dritte Studie über die Verwendung von Bargeldund unbaren Zahlungsinstrumenten. 2015. Available online: https:/ /www.bundesbank.de/resource/blob/599406/8deaa2563cb837cb33d2 d38edef6c4d6/mL/zahlungsverhalten-in-deutschland-2014-data.pdf (accessed on 10 September 2019).

12. Deutsche Bundesbank. Zahlungsverhalten in Deutschland 2017-Vierte Studie über die Verwendung von Bargeld und unbaren Zahlungsinstrumenten. 2018. Available online: https://www.bundesbank.de/resource/blob/634056/8e22ddcd69de76ff40078 b31119704db/mL/zahlungsverhalten-in-deutschland-2017-data.pdf (accessed on 10 September 2019).

13. Lee, I.; Shin, Y.J. Fintech: Ecosystem, business models, investment decisions, and challenges. Bus. Horiz. 2018, 61, 35-46. [CrossRef]

14. Chen, M.A.; Wu, Q.; Yang, B. How Valuable Is FinTech Innovation? Rev. Financ. Stud. 2019, 32, 2062-2106. [CrossRef]

15. Gomber, P.; Kaufmann, R.J.; Parker, C.; Weber, B.W. On the Fintech Revolution: Interpreting the Forces of Innovation, Disruption, and Transformation in Financial Services. J. Manag. Inf. Syst. 2017, 35, 220-265. [CrossRef]

16. Schepinin, V.; Bataev, A. Digitalization of financial Sphere: Challenger banks efficiency estimation. In Proceedings of the International Scientific Conference “Digital Transformation on Manufacturing, Infrastructure and Service", Saint-Petersburg, Russia, 21-22 November 2019.

17. Breidbach, C.F.; Keating, B.W.; Lim, C. Fintech: Research Directions to Explore the Digital Transformation of Financial Service Systems. J. Serv. Theory Pract. 2020, 30, 79-102. [CrossRef]

18. Krasonikolakis, I.; Tsarbopoulos, M.; Eng, T.-Y. Are incumbent banks bygones in the face of digital transformation. J. Gen. Manag. 2020, 46, 60-69. [CrossRef]

19. Fernández-Portillo, A.; Hernández-Mogollón, R.; Sánchez-Escobedo, M.C.; Coca Pérez, J.L. Does the Performance of the Company Improve with the Digitalization and the Innovation? In Economy, Business and Uncertainty: New Ideas for a Euro-Mediterranean Industrial Policy. AEDEM 2017. Studies in Systems, Decision and Control; Gil-Lafuente, J., Marino, D., Morabito, F.C., Eds.; Springer: Cham, Switzerland, 2019; pp. 276-291. [CrossRef]

20. Groberg, M.; Vetter, H.-M.; Flatten, T.C. A measurement instrument for digitization: Scale development and impact on new product performance. In Academy of Management Proceedings 2016; Academy of Management: Briarcliff Manor, NY, USA, 2016. [CrossRef]

21. Kelchevskaya, N.R.; Shirinkina, E.V.; Strih, N.I. Estimation of interrelation of components of human capital and level of digitalization of industrial enterprises by method of modeling of structural equations. In Proceedings of the 1st International Scientific Conference "Modern Management Trends and the Digital Economy: From Regional Development to Global Economic Growth" (MTDE 2019); Atlantis Press: Cambridge, MA, USA, 2019.

22. Niemand, T.; Rigtering, J.P.C.; Kallmüzer, A.; Kraus, S.; Maalaoui, A. Digitalization in the financial industry: A contingency approach of entrepreneurial orientation and strategic vision on digitalization. Eur. Manag. J. 2020. [CrossRef]

23. Dorfleitner, G.; Hornuf, L.; Schmitt, M.; Weber, M. FinTech in Germany; Springer International Publishing: Cham, Switzerland, 2017.

24. Crunchbase. N26. 2019. Available online: https://www.crunchbase.com/organization/n26\#section-twitter (accessed on 4 May 2019).

25. Dorfleitner, G.; Hornuf, L. Fintech-Markt in Deutschland; Bundesministerium der Finanzen: Berlin, Germany, 2016.

26. Christensen, C.M.; Bower, J.L. Customer Power, Strategic Investment, and the Failure of Leading Firms. Strateg. Manag. J. 1996, 17, 197-218. [CrossRef]

27. Christensen, C.M.; Raynor, M.E.; Rory, M. What Is Disruptive Innovation? Harvard Business Review. December 2015, pp. 44-53. Available online: https:/ /hbr.org/2015/12/what-is-disruptive-innovation (accessed on 12 February 2021).

28. Diener, F.; Špaček, M. The Role of “Digitalization” in German Sustainability Bank Reporting. Int. J. Financ. Stud. 2020, 8, 16. [CrossRef]

29. Braun, A. Deutsche Bank voll “Digital”. 2016. Available online: http://boerse.ard.de/aktien/deutsche-bank-voll-digital100.html (accessed on 17 November 2018).

30. Mohan, D. How banks and FinTech startups are partnering for faster innovation. J. Digit. Bank. 2015, 1, 12-21.

31. Matt, C.; Hess, T.; Benlian, A. Digital Transformation Strategies. Bus. Inf. Syst. Eng. 2015, 57, 339-343. [CrossRef]

32. Terrar, D. What is Digital Transformation? 2015. Available online: http://www.theagileelephant.com/what-is-digitaltransformation/ (accessed on 12 May 2020).

33. Valdez-de-Leon, O. A Digital Maturity Model for Telecommunications Service Providers. Technol. Innov. Manag. Rev. 2016, 6, 19-32. [CrossRef]

34. Gartner. Gartner IT Glossary-Digitization. 2020. Available online: https://www.gartner.com/en/information-technology/ glossary / digitization (accessed on 11 May 2020).

35. Francis, B.; Hasan, I.; Küllü, A.M.; Mingming, Z. Should banks diversify or focus? Know thyself: The role of abilities. Econ. Syst. 2018, 42, 106-118. [CrossRef]

36. Hensmans, M. How digital fantasy work induces organizational ideal reversal? Long-term conditioning and enactment of digital transformation fantasies at a large alternative bank (1963-2019). Organization 2020. [CrossRef]

37. Lotriet, R.A.; Dltshego, K.K. An assessment of perceptions concerning digital transformation at a South African commercial bank-A case of Anthropocene denial for the economy. Tydskrif vir Geesteswetenskappe 2020, 60, 687-707. [CrossRef]

38. Von Solms, J. Integrating Regulatory Technology (RegTech) into the digital transformation of a bank Treasury. J. Bank. Regul. 2020. [CrossRef] 
39. Bican, P.M.; Brem, A. Digital Business Model, Digital Transformation, Digital Entrepreneurship: Is There A Sustainable "Digital”. Sustainability 2020, 12, 5239. [CrossRef]

40. Fekete, A.; Rhyner, J. Sustainable Digital Transformation of Disaster Risk-Integrating New Types of Digital Social Vulnerability and Interdependencies with Critical Infrastructure. Sustainability 2020, 12, 9324. [CrossRef]

41. Forcadell, F.J.; Aracil, E.; Ubeda, F. Using reputation for corporate sustainability to tackle banks digitalization challenges. Bus. Strategy Environ. 2020, 29, 2181-2193. [CrossRef]

42. El Hilali, W.; El Manouar, A.; Janati Idrissi, M.A. Reaching sustainability during a digital transformation: A PLS approach. Int. J. Innov. Sci. 2020, 12, 52-79. [CrossRef]

43. Ordieres-Meré, J.; Prieto Remón, T.; Rubio, J. Digitalization: An Opportunity for Contributing to Sustainability FROM Knowledge Creation. Sustainability 2020, 12, 1460. [CrossRef]

44. Moro-Visconti, R.; Cruz Rambaud, S.; López Pascual, J. Sustainability in FinTechs: An Explanation through Business Model Scalability and Market Valuation. Sustainability 2020, 12, 10316. [CrossRef]

45. Verhagen, T. Catalysing FinTech for Sustainability. Lessons from Multi-Sector Innovation. A Report of the BEI's Fintech Taskforce. Preprint. Available online: https://www.researchgate.net/publication/328345987_Catalysing_Fintech_for_Sustainability_ Lessons_from_multi-sector_innovation_A_report_of_the_BEI $\backslash$ T1 $\backslash$ textquoterights_Fintech_Taskforce/comments (accessed on 23 January 2021).

46. Aguayo, F.Z.; Ślusarczyk, B. Risks of Banking Services' Digitalization: The Practice of Diversification and Sustainable Development Goals. Sustainability 2020, 12, 4040. [CrossRef]

47. Moudud-Ul-Huq, S.; Ashraf, B.N.; Gupta, A.D.; Zheng, C. Does bank diversification heterogeneously affect performance and risk-taking in ASEAN emerging economies. Res. Int. Bus. Financ. 2018, 46, 342-362. [CrossRef]

48. Shin, Y.J.; Choi, Y. Feasibility of the Fintech Industry as an Innovation Platform for Sustainable Economic Growth in Korea. Sustainability 2019, 11, 5351. [CrossRef]

49. Mărăcine, V.; Voican, O.; Scarlat, E. The Digital Transformation and Disruption in Business Models of the Banks under the Impact of FinTech and BigTech. In Proceedings of the International Conference on Business Excellence; Walter de Gruyter GmbH: Berlin, Germany, 2020; pp. 294-305. [CrossRef]

50. Hough, J.; Chan, K.-Y. Factors influencing the acceptance of digital banking: An empirical study in South Africa based on the enhanced Technology Acceptance Model. In Proceedings of the 27th Annual Conference of the International Association for Management of Technology (IAMOT 2018), Birmingham, UK, 22-26 April 2018.

51. Sadigov, S.; Vasilyeva, T.; Rubanov, P. FinTech in Economic Growth: Cross-country Analysis. In Economic and Social Development: Book of Proceedings, Proceedings of the 55th International Scientific Conference on Economic and Social Development, Baku, Azerbaijan, 17-18 June 2020; Ismayilov, A., Aliyev, K., Benazic, M., Eds.; ProQuest: Ann Arbor, MI, USA, 2020; pp. $729-739$.

52. Chan, E.S.W. Barriers to EMS in the hotel industry. Int. J. Hosp. Manag. 2008, 28, 187-196. [CrossRef]

53. Chan, E.S.W. Implementing Environmental Management Systems in Small- and Medium-Sized Hotels: Obstacles. J. Hosp. Tour. Res. 2011, 35, 3-23. [CrossRef]

54. Vikneswaran, N.; Anantharajah, S. A green makeover for our hotels? Q. DOE Update Environ. Dev. Sustain. 2012, 2, 10-12.

55. Kamalulariffin, N.S.; Nabiha, S.; Khalid, A.; Wahid, N.A. The barriers to the adoption of environmental management practices in the hotel industry: A study of Malaysian hotels. Bus. Strategy Ser. 2013, 14, 106-117. [CrossRef]

56. Yusof, Z.B.; Jamaludin, M. Barriers of Malaysian Green Hotels and Resorts. In Procedia-Social and Behavioral Sciences, Proceedings of the AMER International Conference on Quality of Life, AicQoL2014KotaKinabalu, The Pacific Sutera Hotel, Sutera Harbour, Kota Kinabalu, Sabah, Malaysia, 4-5 January 2014; Elsevier: Amsterdam, The Netherlands, 2014; pp. 501-509.

57. Chan, E.S.W.; Okumus, F.; Chan, W. What hinders hotels' adoption of environmental technologies: A quantitative study. Int. J. Hosp. Manag. 2020. to be published. [CrossRef]

58. Chan, E.S.W.; Okumus, F.; Chan, W. Barriers to Environmental Technology Adoption in Hotels. J. Hosp. Tour. Res. 2015, 42, 1-25. [CrossRef]

59. Deutsche Bundesbank. Bankenstatistik Januar 2015. Available online: https://www.bundesbank.de/resource/blob/693922/a2 4868217d3ad9478b920930e2226987/mL/2015-01-bankenstatistik-data.pdf (accessed on 9 April 2019).

60. Deutsche Bundesbank. Bankenstatistik Januar 2016. Available online: https://www.bundesbank.de/resource/blob/693932/2 8e421937f44e7c19fee43daf9266b0b/mL/2016-01-bankenstatistik-data.pdf (accessed on 9 April 2019).

61. Deutsche Bundesbank. Bankenstatistik Januar 2018. Available online: https://www.bundesbank.de/resource/blob/693982/7b3 c771cecbc6b44934c408310bbb35f/mL/2018-01-bankenstatistik-data.pdf (accessed on 9 April 2019).

62. Deutsche Bundesbank. Bankenstatistik Januar 2019. Available online: https://www.bundesbank.de/resource/blob/773438/048 ad3c478cd071493582c25ca847a8a/mL/2019-01-bankenstatistik-data.pdf (accessed on 9 April 2019).

63. Deutsche Bundesbank. Bankenstatistik Januar 2020. Available online: https://www.bundesbank.de/resource/blob/822138/b3 d37fcb3c2a65a40ea3ada27a0988d4/mL/2020-01-bankenstatistik-data.pdf (accessed on 9 January 2019).

64. Diener, F. Empirical Evidence of a Changing Operating Cost Structure and Its Impact on Banks' Operating Profit: The Case of Germany. J. Risk Financ. Manag. 2020, 13, 247. [CrossRef]

65. Kuckartz, U. Qualitative Inhaltsanalyse. Methoden, Praxis, Computerunterstützung, 3rd ed.; Beltz Juventa: Weinheim, Germany, 2016.

66. Dresing, T.; Pehl, T. Praxisbuch Interview, Transkription \& Analyse, 6th ed.; Dr. Dresing und Pehl: Marburg, Germany, 2015. 
67. Helfferich, C. Die Qualität Qualitativer Daten: Manual für die Durchführung Qualitativer Interviews, 5th ed.; Springer VS: New York, NY, USA, 2020.

68. Mayring, P. Qualitative Inhaltsanalyse: Grundlagen und Techniken, 12th ed.; Beltz: Weinheim, Germany, 2015.

69. Döring, N.; Bortz, J. Forschungsmethoden und Evaluation in den Sozial- und Humanwissenschaften, 5th ed.; Springer: Berlin/Heidelberg, Germany, 2016.

70. Gläser, J.; Laudel, G. Experteninterviews und Qualitative Inhaltsanalyse als Instrumente Rekonstruierender Untersuchungen, 4th ed.; VS Verlag für Sozialwissenschaften: Wiesbaden, Germany, 2010.

71. Bogner, A. Interviews mit Experten: Eine praxisorientierte Einführung, 2014 ed.; Springer VS: New York, NY, USA, 2014.

72. Glaser, B.G.; Strauss, A.L. The Discovery of Grounded Theory: Strategies for Qualitative Research; Aldine Transaction: Piscataway, NJ, USA, 1967.

73. Morse, J.M. Designing funded qualitative research. In Handbook of Qualitative Research; Denzin, N.K., Lincoln, Y.S., Eds.; Sage Publications: Thousand Oaks, CA, USA, 1994; pp. 220-235.

74. Creswell, J.W. Qualitative Inquiry E Research Design, 3rd ed.; Sage Publications: Thousand Oaks, CA, USA, 2012.

75. Mayring, P. Einführung in die Qualitative Sozialforschung, 6th ed.; Beltz: Weinheim, Germany, 2016.

76. Mayring, P. Einführung in Die Qualitative Sozialforschung. Eine Anleitung zu Qualitativem Denken, 5th ed.; Beltz: Weinheim, Germany, 2002.

77. Brislin, R.W. Translation and content analysis of oral and written materials. In Handbook of Cross-cultural Psychology; Triandis, H.C., Berry, J.W., Eds.; Allyn and Bacon: Boston, MA, USA, 1980; pp. 389-444.

78. Allmark, P.; Boote, J.; Chambers, E.; Clarke, A.; McDonnell, A.; Thompson, A.; Tod, A.M. Ethical Issues in the Use of In-Depth Interviews: Literature Review and Discussion. Res. Ethics 2009, 5, 48-54. [CrossRef]

79. Guest, G.; MacQueen, K.M.; Namey, E.E. Applied Thematic Analysis; SAGE Publications: Thousand Oaks, CA, USA, 2012.

80. Hopf, C.; Schmidt, C. Zum Verhältnis von Innerfamilialen Sozialen Erfahrungen, Persönlichkeitsentwicklung und Politischen Orientierungen: Dokumentation und Erörterung des Methodischen Vorgehens in Einer Studie zu Diesem Thema. Available online: https: / nbn-resolving.org/urn:nbn:de:0168-ssoar-456148 (accessed on 24 August 2020).

81. Fleiss, J.; Levin, B.; Paik, M.C. Statistical Methods for Rates and Proportions, 3rd ed.; John Wiley \& Sons: Hoboken, NJ, USA, 2003.

82. Hallgran, K. Computing Inter-Rater Reliability for Observational Data: An Overview and Tutorial. Tutor. Quant. Methods Psychol. 2012, 8, 23-24. [CrossRef] [PubMed]

83. Rädiker, S.; Kuckartz, U. Analyse qualitativer Daten mit MAXQDA; Springer VS: Wiesbaden, Germany, 2018.

84. Bajpai, S.; Bajpai, R.; Chaturvedi, H.K. Evaluation of Inter-Rater Agreement and Inter-Rater Reliability for Observational Data: An Overview of Concepts and Methods. J. Indian Acad. Appl. Psychol. 2015, 41, 20-27.

85. Carletta, J. Assessing agreement on classification statistics: The kappa statistic. ACL Anthol. 1996, 22, $249-254$.

86. Gewt, K.L. Kappa Statistic is not Satisfactory for Assessing the Extent of Agreement Between Raters. Stat. Methods Inter Rater Reliab. Assess. 2002, 1, 1-6.

87. Ishak, N.M.; Bakar, A.Y.A. Qualitative Data Management and Analysis using NVivo: An Approach used to Examine Leadership Qualities among Student Leaders. Educ. Res. J. 2012, 2, 94-103.

88. Landis, J.R.; Koch, G.G. The measurement of observer agreement for categorical data. Biometrics 1997, 33, 159-174. [CrossRef]

89. Brennan, R.L.; Prediger, D.J. Coefficient kappa: Some uses, misuses, and alternatives. Educational and Psychological Measurement. Educ. Psychol. Meas. 1981, 41, 687-699. [CrossRef]

90. Diener, F.; Špaček, M. The Awareness of Digitisation in Strategic Sustainability Reporting in Banking. In Innovation Management, Entrepreneurship and Sustainability 2019 (IMES 2019), Proceedings of the 7th International Conference, Prague, Czech Republic, 30-31 May 2019; Dvouletý, O., Lukeš, M., Mísař, J., Eds.; Prague University of Economics and Business: Prague, Czech Republic, 2019; pp. $137-150$. 